\title{
Get Real! \\ Individuals Prefer More Sustainable Investments
}

\author{
Rob Bauer* Tobias Ruof ${ }^{\dagger} \quad$ Paul Smeets ${ }^{\ddagger}$
}

November 19, 2018

\begin{abstract}
Do people put their pension savings on the table to promote sustainability? We answer this question in a large-scale field experiment $(\mathrm{n}=3,256)$. The pension fund in our study gave its members a real vote for more or less sustainable investments. A comparison group made the same decision, but hypothetically. We find that $66.7 \%$ of the participants favor to invest their pension savings in a sustainable manner. This choice is driven by social preferences. As a result of these strong social preferences we find no difference between the real and hypothetical treatment groups. We rule out financial beliefs, confusion, or a lack of information as explanation. Institutional investors benefit from taking their clients' social preferences seriously, with consequences for asset prices and the fulfillment of the United Nations Sustainable Development Goals.
\end{abstract}

Keywords: field experiment, social preferences, socially responsible investments, sustainable finance, experimental finance

We are grateful to Pensioenfonds Detailhandel for enabling us to collect the data used in this paper and we particularly thank Henk Groot, Henk van der Kolk, Andre Snellen, and Rene Upperman. We thank seminar participants at Radboud University, at Nijmegen University, and at Maastricht University. We are also grateful to the valuable comments of Jaap Bos, Inka Eberhardt, Piet Eichholtz, Peiran Jiao, Matthijs Korevaar, Joyce Mertens, Luuk Perik, Thomas Post, Drazen Prelec, Paulo Rodrigues, Lidwien Sol, Martin Strobel, Matthias Wibral, and Leonard Wolk. This paper is financially supported by an Inquire grant.

*Department of Finance, Maastricht University (MU) and European Centre for Corporate Engagement (ECCE), School of Business and Economics, Maastricht University (e-mail: r.bauer@maastrichtuniversity.nl) and International Centre for Pension Management (ICPM), Toronto, Canada.

${ }^{\dagger}$ Department of Finance, MU and ECCE (e-mail: t.ruof@maastrichtuniversity.nl)

${ }^{\ddagger}$ Department of Finance, MU and ECCE, Maastricht University (e-mail: pm.smeets@maastrichtuniversity.nl) 


\section{Introduction}

People often claim to behave in a sustainable manner, but do not back their talk by action. ${ }^{1}$ They state to care for animal well-being but buy the cheapest meat in the supermarket (Klink and Langen, 2015). The hypothetical gap is the difference between what people say they do and what they actually do. It is the difference between stated preferences and revealed preferences (List and Gallet, 2001; Carson et al., 2006; Harrison, 2006a; Beshears et al., 2008). ${ }^{2}$ We compare sustainable investment decisions with real consequences to hypothetical decisions. ${ }^{3}$ Sustainable investments grew in importance over the last years. They comprise more than a quarter of the assets under management worldwide (McKinsey, 2017). ${ }^{4}$ The implementation of the 2015 United Nations Sustainable Development Goals further illustrates the societal relevance of sustainable behavior. Consequently, sustainable investment behavior has attracted increased attention from academics (e.g. Hong and Kostovetsky 2012; Krüger 2015; Bialkowski and Starks 2016; Barber et al. 2018; Riedl and Smeets 2017; Hartzmark and Sussman 2018; Krüger et al. 2018).

Understanding why people invest sustainably is not only important to academics, but also to institutional investors who often invest on behalf of individuals. Pension funds alone hold more than half of all assets under management (Willis Tower Watson, 2018). ${ }^{5}$ How should pension funds manage their fiduciary duty regarding sustainable investments? How should they decide on behalf of their clients? The European Commission installed a High-Level Expert Group on Sustainable Finance in 2017. They introduced a formal requirement that "Investment firms. . . [should ask retail investors] about their preferences for sustainable investments." 6

\footnotetext{
${ }^{1}$ See for example Cummings and Taylor (1998, 1999); List and Shogren (1998a,b, 2002); List (2001); Ajzen et al. (2004); Harrison et al. (2004); Harrison (2006b); Vermeir and Verbeke (2006); Beshears et al. (2008); Harrison and Rutström (2008); Gracia et al. (2011); FeldmanHall et al. (2012); De-Magistris et al. (2013); Terlau and Hirsch (2015); for an overview see Harrison (2006b); Loomis (2014); for a meta-study see List and Gallet (2001); Murphy et al. (2005).

2 The gap between what people say and what they do has received various names next to the hypothetical gap, namely: the hypothetical bias, the intention-behavior gap, the attitude-behavior gap, normative vs revealed preferences, the value-action gap, the judgment-action gap, or the green gap (without claiming completeness). In this paper, we will refer to it as hypothetical gap.

${ }^{3}$ Examples for findings of a hypothetical gap outside the economics literature are Rhodes and de Bruijn (2013) who find a gap between the intention to engage in physical activity (hypothetical) and actual engagement (see also Jennings et al. 2015; Osman and Wiegmann 2017). John et al. (2012) report a gap between reported and actual questionable medical research practices. And the question of moral decision-making has led psychologists and moral philosophers to study the gap between hypothetical and real choices. The judgment-action gap thereby describes the difference between what people say they do when being confronted with a moral decision and what they actually do. FeldmanHall et al. (2012) show that real moral decisions can substantially differ from hypothetical moral decisions.

${ }^{4}$ McKinsey (2017) reports that investments according to environmental, social, and governance principles are growing by an annual rate of $17 \%$. In the United States, sustainable investments account for over a third and in Europe for half of all assets (JP Morgan, 2018).

${ }^{5}$ According to an estimate by Willis Tower Watson (2018), pension funds worldwide hold USD 45 trillion assets under management.

${ }^{6}$ See https://ec.europa.eu/info/sites/info/files/180524-sustainable-finance-factsheet_en.pdf.
} 
We provide a scientifically valid method to elicit these preferences. We conducted a largescale field experiment $(\mathrm{n}=3,256)$ in cooperation with a Dutch pension fund which had 18.7 billion euros of assets under management in 2016. ${ }^{7}$ This defined-benefit pension fund invests on behalf of its members. As part of our experiment, the board of the pension fund gave its members a real vote on its future sustainable investment strategy. Participants faced the choice of more or less sustainable investments. The board guaranteed that it will implement the outcome of the voting. Pension savings of the members are at stake, so the choice is relevant. We told participants that sustainable investments not only focus on financial returns but also on societal returns. Our experiment had different treatments. Next to the real choice, another group made a hypothetical choice which was identical, but without consequences.

Our experimental design has three key advantages. First, the consequential vote with only two choices makes our experiment incentive-compatible (Cummings et al., 1995, 1997; Harrison, 2006a; Carson and Groves, 2007). ${ }^{8,9}$ We are not aware of any pension fund that gave its members a consequential vote on the investment strategy of the whole pension plan. Second, the political preferences of our sample are close to the outcome of the last national election in the Netherlands. This is important, because it assures that our sample did not overrepresent voters in favor of sustainable investing (like supporters of the Green Party or the Animal Party), nor underrepresent voters of parties known to be skeptical about sustainability ${ }^{10}$. Third, we published a pre-analysis plan of our study at the Open Science Framework ${ }^{11}$, in which we specified our measures, sampling procedure and analyses.

We find that $65.4 \%$ of participants in the hypothetical treatment favor to invest their pension savings more sustainably. Only $9.6 \%$ are against it and $25.0 \%$ do not have an opinion. Strikingly, hypothetical answers do not differ from real answers. In the real treatment, $67.9 \%$ are in favor of investing more sustainably. We also find no difference among those who are against the sustainable expansion (Real: 10.8\%; Hypothetical: 9.6\%) and a very small difference among those with no opinion (Real: 21.2\%; Hypothetical: 25.0\%). Across both treatments, the ratio of those in favor of more sustainable investments to those against is 6.5 to 1 (four SDGs: $66.7 \%$, three SDGs: $10.3 \%$ ).

Why do we not find a hypothetical gap? We explore three possibilities. First, participants might expect sustainable investments to financially outperform conventional investments and would thus choose more sustainable investments regardless of their treatment. Second, participants could have strong social preferences in favor of sustainable investments in which case

\footnotetext{
${ }^{7}$ See https://www.ipe.com/Uploads/v/a/k/Top-1000-European-Pension-Funds.pdf.

${ }^{8} \mathrm{~A}$ choice set with more than two choices opens the door for strategic voting. Imagine a person has to choose from three options $A, B$, and $C$ and the option chosen by the majority will be implemented. Further imagine the person's preferences to be $A \succ B \succ C$. If she expects that option A will be chosen by only very few people, it can be optimal for her to pick option B to at least avoid option C. This would however imply that she did not pick the option which maximized her utility. Therefore, the choice is not incentive-compatible.

${ }^{9}$ The lacking incentive-compatibility of stated preferences can be of serious concern as it opens the door for interfering answering motives such as socially desirable answering (e.g. Lusk and Norwood 2009; Grimm 2010; Norwood and Lusk 2011; Klink and Langen 2015).

${ }^{10}$ Several studies show that political preferences are a valid proxy for social preferences: Fisman et al. (2017); Kerschbamer and Müller (2017); Almås et al. (2016); Cohn et al. (2018).

${ }^{11}$ See https://osf.io/pz7rn/.
} 
hypothetical and real choices would be the same. Take a vegan who chooses a vegetable dish over meat in both a hypothetical and real setting. Third, subjects might have been confused or did not take their real choice seriously. This would render the real choice to be of mere hypothetical nature.

We show that financial beliefs do not drive the choice for more sustainability through two key findings. First, we find a majority voting for the more sustainable option even among those who should be least likely to vote in favor, specifically subjects who expect lower financial returns with more sustainable investments and subjects who are uncertain about the returns. Second, $42.4 \%$ of participants in the real treatment are willing to give up financial returns in order to invest more sustainably. This question was asked directly after their vote and thus should have made respondents more reluctant to state that they are willing to accept lower returns as they knew that their choice might be implemented. Much rather, we find strong social preferences to drive the choice for more sustainable investments. First, a validated measure of social preferences (Falk et al., 2016) is positively related to the choice for more sustainable investments. Second, we find that people who voted for a political party with a stronger sustainability agenda are more likely to support more sustainable investments by the pension fund. Third, the choice for sustainable investments is not influenced by different defaults. The absence of default effects is another sign of strong preferences. ${ }^{12}$ Expectations on the financial performance do not drive our results. Even among those who expect lower returns, the majority favors sustainable investments. Moreover, $42.3 \%$ of participants explicitly indicate to accept lower financial returns on more sustainable investments. We also show that confusion or lack of information do not drive our results.

Our paper makes three main contributions. First, we contribute to the discussion on sustainable investing. Previous findings show that investors value sustainability in their investment decisions (Bollen, 2007; Hong and Kostovetsky, 2012; Barber et al., 2018; Hartzmark and Sussman, 2018). Yet, these aggregate-level studies cannot inform institutional investors how to invest on behalf of their clients. The data do not show what fraction of individuals has strong social preferences. Riedl and Smeets (2017) use individual-level data to show that sustainable investors indeed have strong social preferences. However, in their study individuals invest on their own behalf and their investment decisions cannot simply be generalized to a setting of delegated portfolio management. In particular, if people's pension is at stake, choices could be very different. We show that social preferences play an important role in delegated investment decisions. Pension fund members are even willing to forego financial returns to invest in a sustainable manner.

Second, we add to the literature on the hypothetical gap. In contrast to most of this literature, we find no hypothetical gap (e.g. Brown et al. 1996; List and Shogren 1998a; Loomis et al. 2009). Previous papers identify different factors that contribute to the existence of a hypothetical gap, such as socially desirable answering (e.g. Lusk and Norwood 2009; Grimm

\footnotetext{
${ }^{12}$ Two of the main drivers responsible for the status quo bias are loss aversion and regret avoidance (Samuelson and Zeckhauser, 1988; Kahneman et al., 1991; Tversky and Kahneman, 1991; Feldman et al., 1999; Nicolle et al., 2011) which should especially matter for choices with real consequences.
} 
2010), certainty of choices (Champ et al., 1997; Ethier et al., 2000; Champ and Bishop, 2001), trust (Terlau and Hirsch, 2015), the perceived effectiveness of one's own choice (Kollmuss and Agyeman, 2002; Fowler III and Close, 2012; Salomon et al., 2017; Berger and Corbin, 1992), the seriousness of the task (De-Magistris et al., 2013), or whether people feel responsible (Blake, 1999). We show that it is also crucial to measure the strengths of people's preferences. If these preferences are weak, a hypothetical gap is more likely to arise than with strong preferences. In our case, the absence of the hypothetical gap in sustainable behavior can be explained by strong social preferences.

Third, we contribute to a growing stream of literature on social preferences in the field (e.g. Frey and Meier 2004; Gneezy and List 2006; List 2006; Gneezy et al. 2010; DellaVigna et al. 2012; Andreoni et al. 2017; Kessler et al. 2018). Specifically, we study how pension funds should deal with the social preferences of their clients. It has become commonplace to acknowledge the influence of time preferences on retirement decisions (O'Donoghue and Rabin, 1998; Carroll et al., 2009; Beshears et al., 2014; Goda et al., 2015). Similarly, several studies show how to elicit risk preferences of pension fund participants (Donkers et al., 2012; Alserda et al., 2016). However, social preferences are not yet considered (EUROSIF, 2016, p. 82). Investment managers often fear that this is too difficult and too costly. ${ }^{13}$ Such concerns could lead to a poor execution of the European Commission's directive. We show a simple, validated way to elicit preferences for sustainable investments. If pension funds take these preferences seriously, this can have a large economic and societal impact.

\section{The experimental design}

In June 2018, we invited 49,552 active members of Pensioenfonds Detailhandel to participate in our online survey. The survey consisted of three parts. Part 1 briefly familiarized all respondents with the concept of sustainable investments and introduced the United Nations Sustainable Development Goals (SDGs). ${ }^{14}$ You can find the instructions and questions we use in Appendix 8. In Part 2, we introduced our 2x2 between-subjects experimental design (see Table 1). Respondents were randomly assigned to one of four groups and were unaware of the existence of other treatment groups. The 2x2 design comprised the dimensions (real choice vs hypothetical choice) x (3 SDG default vs 4 SDG default). We explain these treatments in more detail below. Part 3 elicited social preferences and financial return expectations regarding sustainable investments. Further, we asked respondents to provide information on their gender, age, and education; on their financial background; and on their voting behavior in the 2017 Dutch national elections. Part 3 was identical across all treatments.

\footnotetext{
${ }^{13}$ See, for example, a statement by the BVI, a German investment fund association representing asset managers with over EUR 3 trillion assets under management (https://www.bvi.de/fileadmin/user_upload/Regulierung/ Positionen/2018_06_21_BVIs_view-MiFID_II_sustainability_requirements.pdf).

${ }^{14}$ For more information, see https://www.un.org/sustainabledevelopment/sustainable-development-goals.
} 
TABLE 1 - The experimental 2x2 design.

\section{Real}

Hypothetical
3 SDG default 4 SDG default

I

III
II

IV

In Part 1, respondents learned that they would decide on the sustainable investment strategy of their pension fund. The exact framing of the decision depended on the respective treatment (see below). Importantly, all respondents learned, irrespective of their treatment, that they would have to state whether their pension fund should focus on three or four Sustainable Development Goals (SDGs). We explained that investing according to an SDG meant that The Pension fund would engage with the companies' board to assure that the company's policy and actions are aligned with the respective SDG. We told them that in 2017 Pensioenfonds Detailhandel had spoken with a total of 246 corporate boards to promote sustainability. In addition, we gave them several examples of earlier SDG engagement by the Pension Fund. We explicitly pointed out that focusing on four SDGs would result in more sustainable investment activities than focusing on three SDGs.

\section{Hypothetical vs Real}

The first dimension of our 2x2 design consists of the difference between hypothetical vs real choices. Participants in the hypothetical treatment learned that "Pensioenfonds Detailhandel is genuinely interested in your opinion and may take the results of the survey into account when making a decision." Participants of the real treatment learned that "Your choice counts. If the majority of respondents chooses to add a (leave out the) fourth sustainable development goal, it will happen. The board of Pensioenfonds Detailhandel guarantees its implementation." The majority vote of $50 \%$ thus determines the degree to which the pension fund focuses on more or less sustainable investments. Respondents in the real treatment further learned that the board would report on the outcome of the vote publicly and that the actual implementation of the sustainable investments would be done by investment experts.

\section{SDG default vs 4 SDG default}

The second dimension of our 2x2 design consists of the difference between a 3 SDG default and a 4 SDG default. Staying with the default option is a widely found phenomenon, also called the status quo bias (e.g. Samuelson and Zeckhauser 1988; Tversky and Kahneman 1991). Two of its main drivers are loss aversion and regret avoidance (e.g. Samuelson and Zeckhauser 1988; Kahneman et al. 1991; Tversky and Kahneman 1991; Feldman et al. 1999; Nicolle et al. 2011) which are significantly more important to respondents in the real treatment than to those in the hypothetical treatment. With the introduction of different defaults, we can account for differences in the status quo effect on real and hypothetical choices. 
In the $3 \boldsymbol{S D G}$ default treatment, we told participants that the pension fund currently focuses on three SDGs, namely: 'Climate action', 'Decent work and economic growth', and 'Peace, justice, and strong institutions'. Participants were then introduced to the fourth SDG 'Responsible consumption and production'. They could choose:

"Do you want Pensioenfonds Detailhandel to add the fourth sustainable development goal 'Responsible consumption and production'?

a. Yes, add

b. No, do not add

c. I have no opinion regarding this matter"

In the $4 \boldsymbol{S D G}$ default treatment, we told participants that the pension fund's future policy will include four SDGs 'Climate action', 'Decent work and economic growth', 'Peace, justice, and strong institutions' and 'Responsible consumption and production'. Participants could then decide:

"Do you want Pensioenfonds Detailhandel to leave out the fourth sustainable development goal 'Responsible consumption and production'?

a. Yes, leave it out

b. No, do not leave it out

c. I have no opinion regarding this matter"

Importantly, the question of interest - whether Pensioenfonds Detailhandel should focus on three or on four SDGs - was the same for all four treatments except for the words 'add' or 'leave out'. Respondents could either choose to add (3 SDG default) or to leave out (4 SDG default) the fourth SDG. In addition, respondents always had the answer option 'No opinion'. Further, everything besides the necessary information within each treatment group was exactly the same. The $2 \mathrm{x} 2$ design therefore allows us to directly capture the effect of consequentiality on the subject's choices by taking into account their status quo. The binary nature of the choice is essential as it assures incentive compatibility (see Cummings et al., 1995; 1997; Harrison, 2006a; Carson and Groves, 2007). Providing participants with multiple options, like choosing between adding different SDGs, would have introduced incentives for strategic voting (see Arrow's impossibility theorem; Arrow, 2012). For example, if participants expect that it is unlikely that their first best choice will get a majority vote, they can strategically vote for the second-best option. 


\section{The data}

\subsection{The participants}

Participants in our study are members of Pensioenfonds Detailhandel, a large Dutch pension fund. The Dutch state requires employees to save for their pension. It is mandatory for participants to contribute to the pension fund through their current employer. Of the invited 49,552 participants, 5,047 (10.2\%) started and 2,507 (5.1\%) completed the survey. Table A.2 presents summary statistics of the respondents. The sample consists of $61.5 \%$ women and $38.5 \%$ men, with an average age of 46.4 years. Slightly less than a third have a university degree or a degree from a university of applied sciences (29.4\%). The average monthly net household income is 2,868 Euro.

Table A.3 shows that our randomization into the real and hypothetical choice treatments worked. We do not find any significant differences between the treatment groups regarding their preferences, demographic characteristics and financial background.

\subsection{Representativeness of our sample}

Surveys face the risk of a biased response sample. This is of special concern in a setting like ours, where the topic is sustainable investing and people with stronger social preferences might be more likely to participate in the survey. Yet, our sample is fairly representative of the invited population. Our sample contains slightly fewer women (61.5\% vs 66.5\%) and is slightly older (46.4 years compared to 42.6 years). The yearly income in our sample is 25,832 euro compared to 24,295 euro in the invited sample. As we show below, men, older people, and people with a higher income are less likely to expand sustainable investing. Hence, these differences go against our findings and thus cannot explain our results.

Second, we tested whether participants in our study have stronger social preferences than non-respondents, which would likely result in an upward bias in the support for more sustainable investing at the pension fund. We therefore asked participants to provide information on whether they voted in the Dutch national elections in 2017 and, in case they did, to name the party they voted for. Voting behavior is a good proxy for social preferences, because the relation between social preferences and voting behavior has been well-established. Fisman et al. (2017) show that equality-focused subjects were more likely to vote for Barack Obama in 2012 and are also more likely to be affiliated with the U.S. Democratic Party. Kerschbamer and Müller (2017) find that social preferences predict political attitudes. Almås et al. (2016) find conservatives to systematically accept a higher level of inequality than non-conservatives. Hong and Kostovetsky (2012) show that U.S. investment managers who donate to the Democratic Party are more likely to invest in companies which are seen to be socially responsible. Hence, by comparing the voting behavior of our sample to the outcome of the 2017 Dutch national elections, we can observe whether we attracted certain voters more than others resulting in a non-representative distribution of preferences. Table A.4 presents the voting behavior of our sample. 2,647 respondents answered the question of which 139 did not want to state whether 
they voted. The reported voter turnout was $85.4 \%$ which is close to the official turnout of 81.6\%. ${ }^{15}$ This is a first indication that our sample is close to representative for the voting behavior in the Netherlands. Of the 2,142 respondents who voted, 562 (26.2\%) did not want to state the name of the party they voted for. The distribution of votes for the remaining 1,580 respondents resembles the official voting outcome very closely. Importantly, the voter outcome for parties known to strongly advocate sustainability like the green party (GroenLinks) and the animal party (Partij voor de Dieren) is close to the official outcome. This is a strong indicator that we do not have a selection bias of certain preferences which favor sustainable investing. The only clear difference between the reported voting behavior in our sample and the official turnout is the share reporting to have voted for the PVV, a Dutch populist party ${ }^{16}$. Yet, this finding is in line with previous work showing that people refrain from admitting their support for extreme groups (Gingerich, 2010; Bullock et al., 2011).

Hence, our sample is close to representative in terms of demographics, financial background, and social preferences. We will show below that small differences in the characteristics of our respondents cannot explain our results but even go against our results.

\section{Results}

\subsection{The hypothetical gap}

In the hypothetical treatment, two thirds (65.4\%) of respondents preferred an increased focus on sustainable investments and chose four SDGs (see Figure 1) ${ }^{17}$. Only 9.6\% of respondents chose three SDGs, while 25.0\% reported to have no opinion. How do respondents choose when their decisions have real consequences? The literature on the hypothetical gap argues that respondents should be less likely to choose four SDGs. In contrast to this expectation, $67.9 \%$ of participants in the real treatment favored more sustainable investments and chose four SDGs, which is almost exactly the same as in the hypothetical treatment ( $\mathrm{p}$-value $=0.1245)$. Similarly, choices in favor of three SDGs barely differ between the real and hypothetical choices $(10.8 \%$ in the real treatment and $9.6 \%$ in the hypothetical treatment; p-value $=0.2579$ ). Hence, in contrast to our expectation and the majority of findings in the literature, the difference between real and hypothetical choices is non-existent. Only the difference among those without an

\footnotetext{
$\overline{15}$ The official 2017 parliamentary election results can be found online at https://www.verkiezingsuitslagen.nl/ verkiezingen/detail/TK20170315.

${ }^{16}$ Its leader, Geert Wilders, "told supporters he would ensure there were 'fewer Moroccans' in the country" during an election campaign in 2014 (https://www.theguardian.com/world/2014/mar/20/dutch-politiciangeert-wilders-moroccans-outrage-pvv-party-anti-islam). As a consequence, he was found guilty of inciting racial discrimination in December 2016 (https://www.telegraph.co.uk/news/2016/12/09/anti-islam-dutchmp-geert-wilders-found-guilty-discrimination/). He has further mentioned that he wants to ban all mosques in the Netherlands (https://www.independent.co.uk/news/world/europe/netherlands-pvv-leader-geert-wilderskoran-islam-mosque-ban-holland-dutch-pm-favourite-a7214356.html).

${ }^{17}$ For now, we do not differentiate between the 3 SDG default and 4 SDG default treatments and look at them jointly. We will get back to this in the next section.
} 
opinion is significant, but small in economic terms (real: $21.2 \%$; hypothetical: $25.0 \%$; p-value $=0.0112$ ). It could indicate that respondents in the real choice treatment do not shy away from taking responsibility through voting.

Overall, we find a clear majority of $66.7 \%$ of participants across all treatments to favor more sustainable investing. Remarkably, respondents in favor of four SDGs are 6.5 times as many as those against it (four SDGs: 66.7\%, three SDGs: 10.3\%).

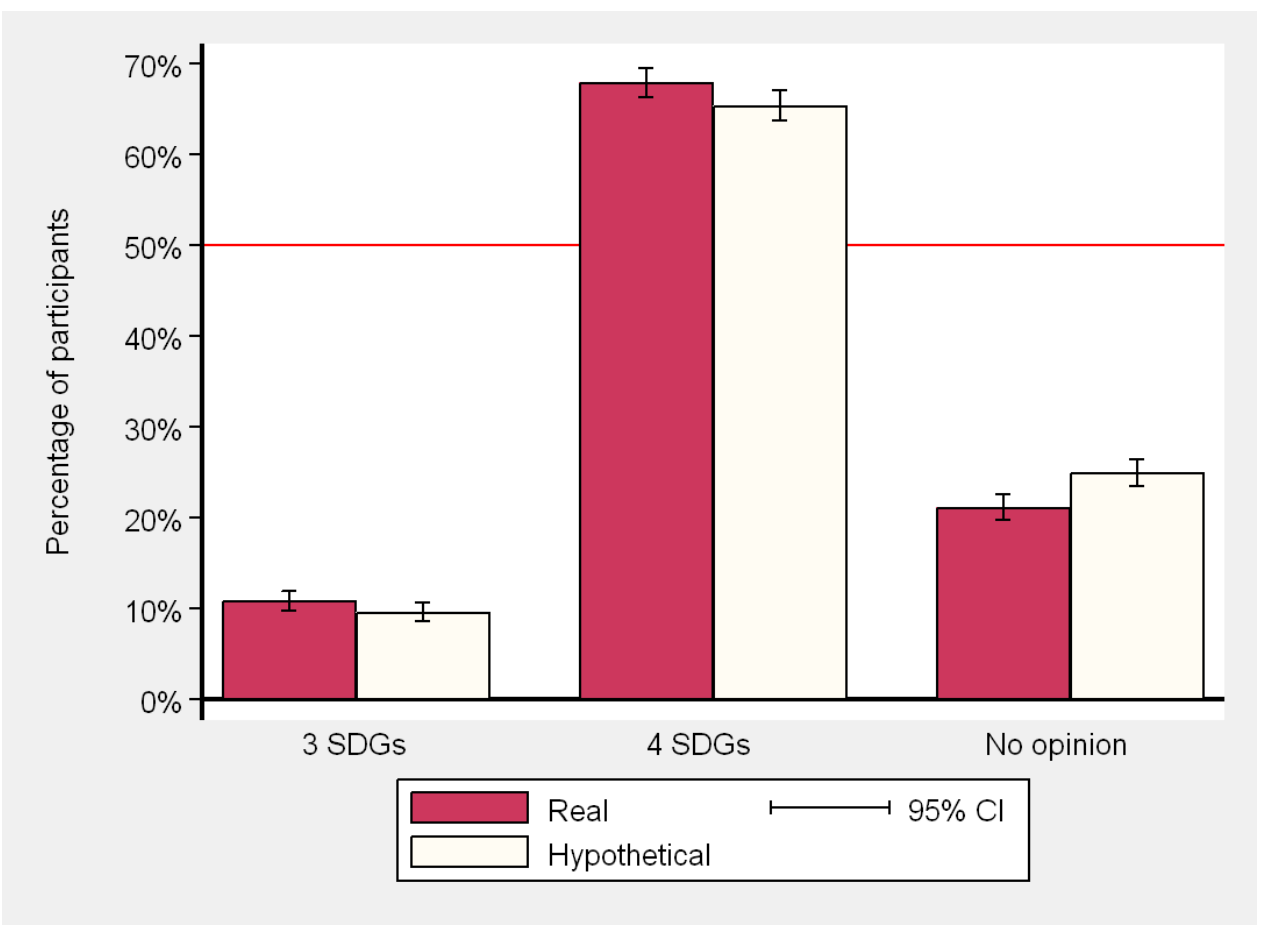

\section{FigurE 1 - The distribution of real and hypothetical choices.}

The graph presents the distribution of real and hypothetical choices regarding the following question: "Do you want Pensioenfonds Detailhandel to add (leave out) the fourth sustainable development goal 'Responsible consumption and production'?". Answer options were 'Yes, add (leave it out)', 'No, do not add (leave it out)', and 'I have no opinion regarding this matter'. Words in parentheses refer to the different status quo treatments which are looked at jointly here. The graph presents the distribution of real and hypothetical choices separately, which refers to whether answering the above-stated question was consequential or not. In the hypothetical treatment, choices were nonconsequential. In the real treatment, choices were guaranteed to be implemented by the pension fund if more than $50 \%$ of respondents would choose in favor of three, respectively four SDGs. Error bars present $95 \%$ confidence intervals. Non-overlapping error bars indicate a statistically significant difference at the $5 \%$ level between the treatments real and hypothetical within each answer category.

Result 1: $66.7 \%$ of respondents are in favor of expanding sustainable investments. Surprisingly, there is no difference between hypothetical and real choices.

Why do we find no hypothetical gap? There are three potential explanations. First, it could be that the real choice in fact looks like a hypothetical choice or that people are confused. Consequently, there would be no difference between real and hypothetical choices. Second, people could decide to invest sustainably as they expect these investments to financially outperform conventional investments. If return expectations are sufficiently high, everybody would opt for more sustainable investments regardless of the consequentiality of their choice. Third, participants can have strong preferences for sustainable investments. People who have strong 
preferences about their choice are unaffected by whether it is of real or hypothetical nature. A vegan would choose vegetables over meat no matter whether the choice is real or hypothetical. People with weaker preferences, however, tend to sway between real and hypothetical choices. Someone might say that she cares for the environment but if asked to pay the voluntary premium to make her flight CO2 neutral, she passes. Another person might talk a lot about sustainability, but when given the chance to expand sustainable investments using his pension savings, he votes against it.

In the following sections, we show that the absence of a hypothetical gap in our sample is the result of strong social preferences.

\subsection{Financial return expectations}

In this section, we explore how expectations about financial performance influence sustainable investment choices. An important design feature is how to introduce costs and benefits of sustainable investments. We told participants that investing according to the Sustainable Development Goals means that not only the financial return counts. For those investments it is also important to consider the impact on the environment and society. We deliberately did not mention absolute costs or benefits of sustainable investments, because these are simply unknown. Several studies show that sustainable investments outperform conventional investments (Derwall et al., 2005; Edmans, 2011), but other studies rather find an underperformance (Hong and Kacperczyk, 2009; Barber et al., 2018; Riedl and Smeets, 2017; Hartzmark and Sussman, 2018). The return expectations of individual investors reflect these ambiguous findings regarding realized returns on sustainable investments. Some studies find investors to expect lower risk adjusted returns (Renneboog et al., 2008; Riedl and Smeets, 2017). Others find investors to expect higher risk-adjusted returns on sustainable investments (Hartzmark and Sussman, 2018).

We also asked participants about their financial return expectations when the pension fund would focus on 3 or 4 SDGs respectively. Specifically, we asked participants:

"When do you think the investment return is highest?

a. It is highest with 3 SDGs.

b. The return is equally high with 3 or 4 SDGs.

c. It is highest with 4 SDGs.

d. I do not know."

Figure 2(a) plots the distribution of financial beliefs within our sample. The majority of $56.4 \%$ of participants provided a return expectation; $16.3 \%$ of participants expect a lower return with four SDGs (answer a), $15.4 \%$ expect a higher return, and $24.7 \%$ of respondents think that there is no difference in returns between investing in three or four SDGs. Return expectations are clearly not overly favorable toward sustainable investing and are thus unable to explain that two thirds choose to expand sustainable investments at their pension fund. 


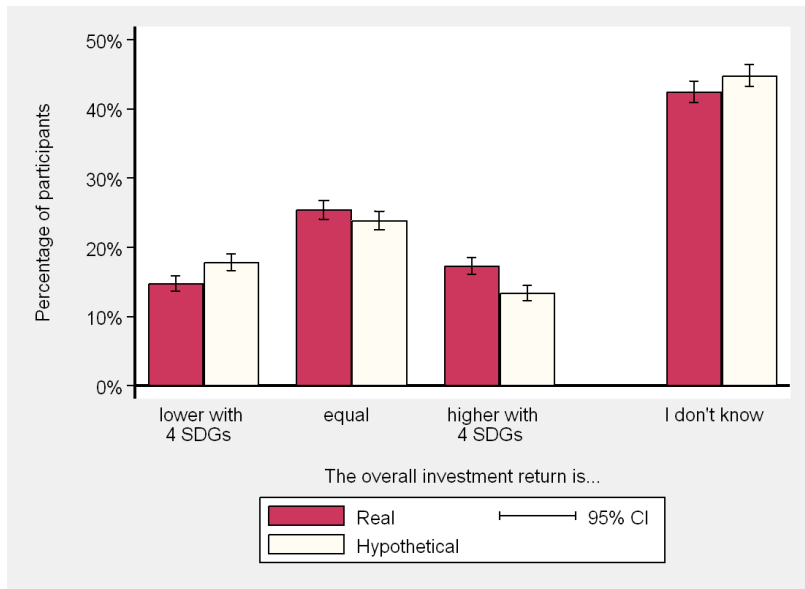

(a) Distribution of financial beliefs

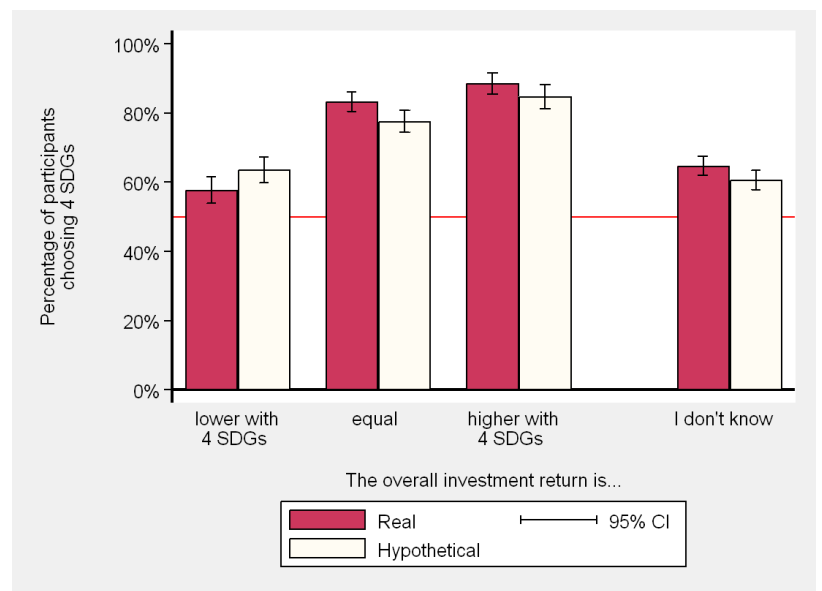

(b) Percentage choosing 4 SDGs per belief category

\section{FIGURE 2 - Financial beliefs.}

Figure 2(a) shows the distribution of financial beliefs. Figure 2(b) presents the percentage of participants choosing four SDGs for each return expectation separately. Return expectations were elicited by asking participants to answer the following question: "When do you think the investment return is highest?" Answer options were 'It is highest with 3 SDGs', 'The return is equally high with 3 or 4 SDGs', 'It is highest with 4 SDGs', and 'I do not know'. The categories shown in Figure 2B refer to the following question: "Do you want Pensioenfonds Detailhandel to add (leave out) the fourth sustainable development goal 'Responsible consumption and production'?". Answer options were 'Yes, add (leave it out)', 'No, do not add (leave it out)', and 'I have no opinion regarding this matter'. Words in parentheses refer to the different status quo treatments which are looked at jointly here. Both figures present the distribution of real and hypothetical choices separately, which refers to whether answering the above-stated question was consequential or not. In the hypothetical treatment, choices were nonconsequential. In the real treatment, choices were guaranteed to be implemented by the pension fund if more than $50 \%$ of respondents would choose in favor of three, respectively four SDGs. Error bars present $95 \%$ confidence intervals. Non-overlapping error bars indicate a statistically significant difference at the $5 \%$ level between the treatments real and hypothetical within each answer category.

Figure 2(b) supports this claim. While we find stronger support for four SDGs if return expectations are more positive, the majority is in favor of four SDGs independent of return expectations. The difference between real and hypothetical choices of four SDGs are nonsignificant. Two findings are especially noteworthy. First, even among those who expect four SDGs to yield lower returns, $60.8 \%$ chose four and only $25.0 \%$ three SDGs. Thus, even when people expect to be worse off, they favor the more sustainable option. Second, literature shows that people do not like uncertainty and therefore avoid outcomes which increase uncertainty (e.g. Ellsberg 1961; Mukerji and Tallon 2001; Charness and Gneezy 2010). We find that of the participants who do not know what returns to expect, $62.6 \%$ favor four SDGs. While this number has to be treated with caution as the uncertain option depends on the default treat- 
ment, we find that the majority of subjects chooses four SDGs irrespective of their default. ${ }^{18}$ Thus, we can confidently say that the majority is in favor of four SDGs independent of return expectations, even if people do not know what to expect.

Last but not least, we asked participants, who expected similar or higher returns with four SDGs, whether they would be willing to accept lower financial returns in order to expand sustainable investments? This question was asked directly after return expectations were elicited and thus shortly after the main question. Respondents in the real treatment thus were aware of the fact that their choice could have an impact on the investment activities of their pension fund. More importantly, the fund could thus also consider a willingness to accept lower returns as the right to give up financial returns in order to increase the social impact of their investments. Figure 3 shows that $42.4 \%$ of participants in the real treatment would go for four SDGs even if it meant lower returns (Hypothetical: 42.1\%, difference: p-value $=0.8761$ ). In other words, participants did not only choose the more sustainable option regardless of their return expectations. Almost half of them were even willing to give up financial returns.

All in all, there is no evidence that participants only support more sustainable investments because they see it as a free lunch.

Result 2: The majority of respondents chooses to expand sustainable investing irrespective of return expectations. A significant share even accepts lower financial returns in exchange.

In the following subsection, we show that the effect of social preferences on the choice for four SDGs is unaffected when we control for return expectations in a multinomial logit regression.

\subsection{Strong social preferences}

We measure social preferences using the validated social preferences measure of Falk et al. (2016) "How willing are you to give to good causes without expecting anything in return?". Participants rate their agreement on a 10-point Likert scale from completely unwilling to very willing. Higher ratings correspond to higher levels of social preferences. The average level of social preferences in our sample is 6.1 on a 10-point Likert scale (for summary statistics, see Table A.2). We investigate to what extent social preferences predict the support for more sustainable investments. Table 2 presents relative-risk ratios of a multinomial logit regression that regresses the support for four sustainable development goals on our measure of social preferences. The dependent variable takes on three values for the choices ' 3 SDGs', '4 SDGs', and 'No opinion'. As baseline, we take respondents who chose three SDGs. To interpret the

\footnotetext{
${ }^{18}$ People in the 3 SDG default should consider the choice of three SDGs to be less uncertain as this is the default option while those in the 4 SDG default should consider the choice of four SDGs to be less uncertain. For those who do not have a return expectation for sustainable investments, we therefore expect that the support for four SDGs is lower in the 3 SDG default than in the 4 SDG default. Figure A.1, shows the default effect for those participants who did not know what return to expect (43.6\% of the entire population, see Figure $2(\mathrm{a}))$. As hypothesized, we do find a significant difference where $59.4 \%$ of participants in the 3 SDG default and $65.8 \%$ of those in the 4 SDG default choose four SDGs (one-sided T-test; p-value $=0.0107$ ). Yet, it is remarkable that even for those who consider choosing four SDGs as the option with higher uncertainty, we find a clear majority to opt for the more sustainable option.
} 


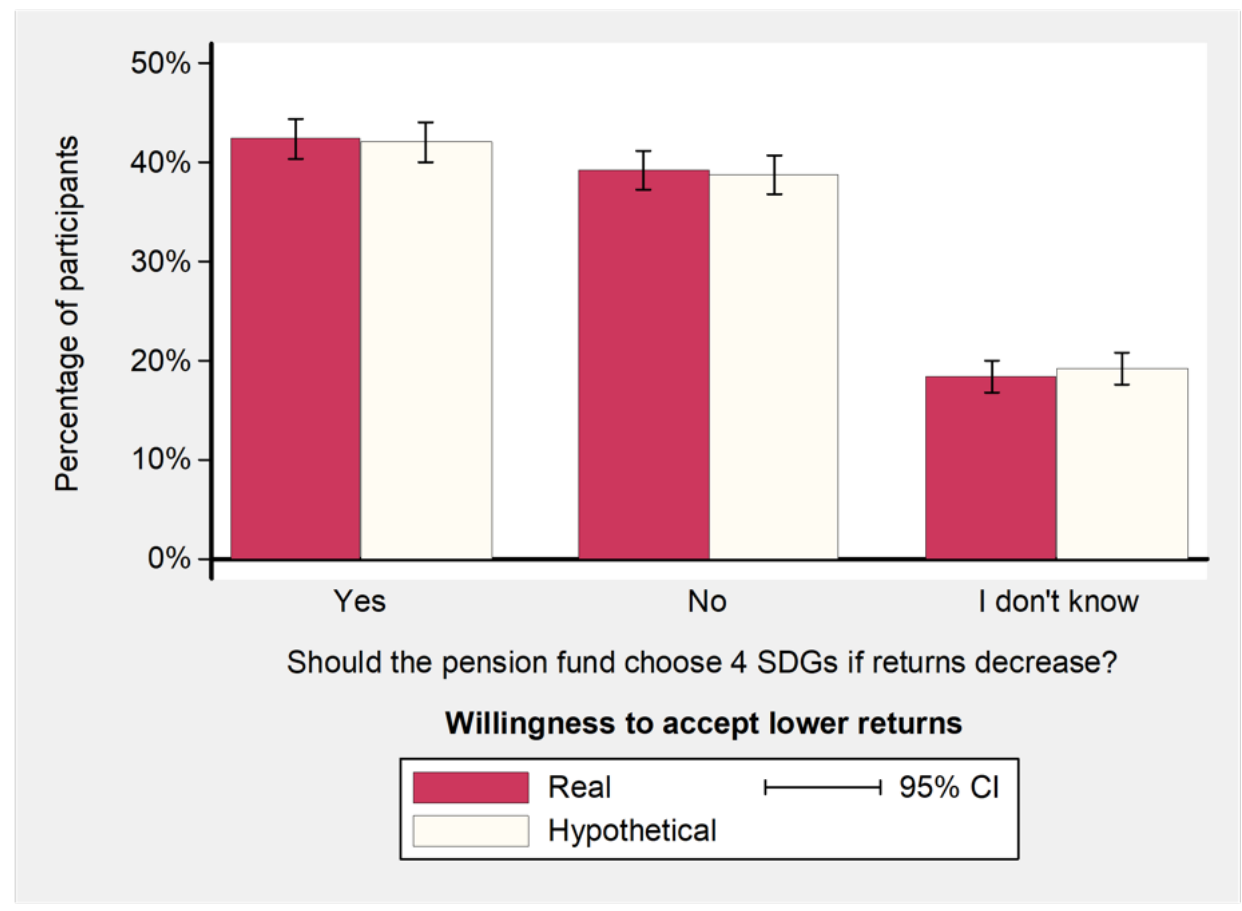

\section{Figure 3 - Accepting lower returns.}

This graph presents the answer distribution of respondents to the question "Do you want Pensioenfonds Detailhandel to opt for four SDGs if the return on investment would decrease?". Answer options were 'yes', 'no', and 'I do not know'. The graph presents the distribution of real and hypothetical choices separately. Real and hypothetical refers to whether answering the question "Do you want Pensioenfonds Detailhandel to add (leave out) the fourth sustainable development goal 'Responsible consumption and production'?" was consequential or not. Words in parentheses refer to the different status quo treatments which are looked at jointly here. The graph presents the distribution of real and hypothetical choices separately, which refers to whether answering the above-stated question was consequential or not. In the hypothetical treatment, choices were nonconsequential. In the real treatment, choices were guaranteed to be implemented by the pension fund if more than $50 \%$ of respondents would choose in favor of three, respectively four SDGs. Error bars present 95\% confidence intervals. Non-overlapping error bars indicate a statistically significant difference at the $5 \%$ level between the treatments real and hypothetical within each answer category.

relative-risk ratios, consider the effect of Gender (female) on the choice for 4 SDGs. If the coefficient equals 1, men and women are equally likely to choose 4 SDGs. A coefficient larger than one indicates that women are more likely to choose 4 SDGs. Similarly, a coefficient smaller than one indicates that women are less likely to choose 4 SDGs.

In the first column of specification (1), we study the effect of social preferences on the likelihood to choose four SDGs. A one standard deviation increase in social preferences increases the likelihood to choose four SDGs by $57.4 \%$. Given that $69.7 \%{ }^{19}$ of our sample chose four SDGs, social preferences have a substantial economic impact on sustainable investment decisions. Social preferences are not related to the choice of no opinion. In specification (2), we control for financial beliefs, demographics, and information on participants' financial background. As anticipated, expecting lower returns decreases the likelihood to choose four SDGs by $76.8 \%$ while expecting higher returns increases the likelihood by $84.6 \%$. Remarkably, we find that

\footnotetext{
19 The actual percentage of $69.7 \%$ differs from the otherwise stated $66.7 \%$ as some subjects answered the main question whether to add a fourth SDG but dropped out of the survey before giving a prediction. Among those, who give a prediction, the percentage of accepting 4 SDGs is slightly higher.
} 
respondents who do not know what returns to expect are 2.4 times more likely to also report that they have no opinion on whether to choose three or four SDGs. This finding supports the hypothesis that these subjects are ambiguity averse which increases the power of our finding that the majority of these subjects still opts for four SDGs (see rightmost bars in Figure 2(b)).

However, with the inclusion of these controls, the effect size of social preferences does not decrease but, on the contrary, slightly increases $(\beta=1.6022)$ showing that social preferences robustly explain the choice for more sustainable investments.

Result 3: Social preferences strongly predict the choice for more sustainable investments and is robust to including financial beliefs. This is consistent with a preference-based explanation for sustainable investments.

Looking more closely at the effects of demographics on sustainable investments in Table 2, we see that women are significantly more likely to choose four SDGs compared to men. Women in our sample also have stronger social preferences than men (F: 6.2 vs M: 5.9; p-value $=0.0079$ ). These results are in line with previous literature findings (see e.g. Bolton and Katok 1995; Eckel and Grossman 1998; Güth et al. 2007; for a meta-analysis see Croson and Gneezy 2009). Remember that our sample has slightly more men compared to the pension fund's population. The support we find for more sustainable investments therefore is on the conservative side. Noteworthy is that even among men the majority opts for more sustainable investments (68.5\%). Second, age is related to the respondents' choice for sustainable investing. Older people are less likely to choose four SDGs. Each 10 years of age decrease the likelihood to choose four SDGs by $17.0 \%$. Given that our respondents are slightly older than the invited sample and older people are less in favor of sustainable investments, the support for sustainable investments is a lower-bound. Third, education has no impact on whether respondents choose three or four SDGs. Not surprisingly, highly educated respondents are $46.3 \%$ less likely to have no opinion. And finally, people with a higher income are slightly less likely to choose four SDGs.

\subsection{Default effects}

In contrast to real choices, hypothetical choices have no consequences. The status quo bias should thus be stronger in the real choice treatment and could hide people's actual preferences (e.g. Samuelson and Zeckhauser 1988; Tversky and Kahneman 1991). Consider receiving investment advice, where the default option is to not focus on sustainable investments. Those who prefer to invest sustainably but fear that returns will be too low stay with the default and do not reveal their actual preferences - which they would in case of a hypothetical survey with the same default. With our different treatments, we are able to differentiate between status quo effects and the consequentiality of choices.

Table 3 shows that the status quo does not affect the choice for more sustainable investments. We again use a multinomial logit regression where the dependent variable takes on the three values '3 SDGs', '4 SDGs', and 'No opinion'. If a status quo bias were present, we would 


\section{TABLE 2 - The effect of social preferences on sustainable investing.}

This table presents relative-risk ratios of a multinomial logit regression where the dependent variable takes on three values for the choices ' 3 SDGs', ' 4 SDGs', and 'I have no opinion regarding this matter'. Baseline are respondents who chose three SDGs. Social preferences are elicited by asking respondents to rate the question "How willing are you to give to good causes without expecting anything in return?" on a 10-point Likert scale from completely unwilling to completely willing (see Falk et al. 2016). Financial beliefs were elicited by asking participants to answer the following question: "When do you think the investment return is highest?" Answer options were 'It is highest with 3 SDGs', 'The return is equally high with 3 or 4 SDGs', 'It is highest with 4 SDGs', and 'I do not know'. For summary statistics, see Table A.2, and for definitions of the other variables, see Table A.1. Significance levels show the difference from one and are indicated by $* * * \mathrm{p}<0.01,{ }^{* *} \mathrm{p}<0.05, *$ $\mathrm{p}<0.1$.

(1)

(2)

4 SDGs No opinion 4 SDGs No opinion

Preferences

Social preferences (std)

$1.5737^{* * *}$

0.9307

$1.6022 * * *$

0.9984

(0.1050)

(0.0704)

$(0.1155)$

$(0.0825)$

Financial beliefs

Lower returns with 4 SDGs

$0.2315^{* * *}$

$0.3502^{* * *}$

Higher returns with 4 SDGs

$(0.0463)$

(0.0917)

$1.8464^{* *}$

1.2984

$(0.5615)$

(0.4702)

Do not know

0.8242

$2.3686^{* * *}$

Demographics

(0.1679)

(0.5606)

Female

$2.0447^{* * *}$

$1.8123^{* * *}$

Age

(0.3057)

$0.9830 * * *$

(0.3187)

(0.0054)

$0.9744^{* * *}$

Financial background

Highly educated

0.9912

(0.0062)

Low monthly income

(0.1631)

$0.5329^{* * *}$

0.9107

(0.1079)

(0.1707)

0.9830

High monthly income

0.7263

(0.2181)

$(0.1717)$

Do not report

$0.6456^{* *}$

0.7661

(0.1330)

Constant

$7.5682^{* * *}$

$1.8056^{* * *}$

$20.7619^{* * *}$

(0.2314)

1.2274

Observations

$(0.5318)$

(0.1494)

(7.5115)

(0.2876)

$4.2414^{* * *}$

(1.7735)

2,529

2,529

2,383

2,383

expect respondents in the 4 SDG default treatment to be more likely to support four SDGs than respondents in the 3 SDG default. Accordingly, the coefficient of ' 4 SDG default' in the first column of specification (1) should be significantly greater than one. The non-significance of the coefficient shows that this is clearly not the case. Framing has no effect on the choice between three or four SDGs. In specification (2), we control for all four treatment groups individually. Given that the status quo effect should be stronger in the real choice treatment, the coefficient of the independent variable '4 SDG default * Hypothetical' should be the largest 
of the three treatment variables and significantly greater than one. The coefficient is indeed the largest $(\beta \approx 1.18)$ but not significantly different from one nor from the other treatment variables.

The non-significance of all coefficients confirms that framing has no effect on the choice to expand sustainable investing. In specification (3), we include financial beliefs, demographics, and information on the financial background as controls. As a consequence of including financial beliefs, the coefficient of '4 SDG default * Hypothetical' turns marginally significant (difference from one: $\mathrm{p}$-value $=0.095)$. This is the result of a statistical difference in return expectations as there are slightly more respondents in the hypothetical treatment who expect higher returns with three SDGs (Hypothetical: 17.9\% vs Real: 14.8\%; p-value $=0.0270$ ). Thus, this effect does not capture an actual hypothetical gap.

More importantly, the effect size and the significance level of social preferences is not affected by including treatment effects which indicates that strong preferences drive the decision to invest sustainably. An individual with strong preferences for sustainable investing will choose more sustainable investments, irrespective of what the default option is, and whether it is a real or hypothetical choice.

Result 4: Respondents' choice of expanding sustainable investments does not depend on how their choice is framed (no status quo dependency). The support for more sustainable investments is always high, consistent with strong preferences.

\subsection{External validation: voting behavior and sustainable invest- ments}

To test for external validity of our results, we explore the relation between the support for more sustainable pension investments and voting behavior in the last national parliamentary elections. We construct respondents' preferences for sustainable policies by evaluating the stance on sustainability of the political party they voted for. We use the official voting guide for the 2017 Dutch national elections. ${ }^{20}$ Five of the 30 questions posed in this voting guide deal with issues related to sustainability. All questions are posed such that they can be answered with 'agree', 'disagree', or 'neither of the two'. A party receives one point for each question for which they choose the more sustainable option. If a party chooses 'neither of the two', it receives half a point. For example, consider the statement "All coal-fired power stations may remain open for the time being." If a party agrees to this statement, it receive zero points; if it disagrees it receive one point; and if it says neither of the two, they receive half a point. Each political party thus receives a score between zero and five. The entire construction of the score is presented in Table A.5.

Table A.6 shows that voters of political parties with a stronger preference for sustainable policies show more support for four SDGs. Especially, voters of the green party (GroenLinks) and the animal party (Partij voor de Dieren) favor four SDGs (89.8\% and 88.9\% respectively).

\footnotetext{
${ }^{20}$ See https://tweedekamer2017.stemwijzer.nl.
} 


\section{TABLE 3 - The effects of consequentiality and status quo dependency on sustainable investing.}

This table presents relative-risk ratios of a multinomial logit regression where the dependent variable takes on three values for the choices '3 SDGs', '4 SDGs', and 'I have no opinion regarding this matter'. Baseline are respondents who chose three SDGs. For summary statistics, see Table A.2. Social preferences are elicited by asking respondents to rate the question "How willing are you to give to good causes without expecting anything in return?" on a 10-point Likert scale from completely unwilling to completely willing (see Falk et al. 2016). 3 SDG default and 4 SDG default refer to two different status quo treatments to which participants were randomly assigned. In the $3 S D G$ default, participants were told that the pension fund currently focuses on three SDGs. Participants were introduced to the fourth SDG 'Responsible consumption and production' and could choose: "Do you want Pensioenfonds Detailhandel to add the fourth sustainable development goal 'Responsible consumption and production'?". Answer options were 'Yes, add', 'No, do not add', and 'I have no opinion regarding this matter'. In the $4 S D G$ default treatment, it was communicated that the pension fund's future policy will include a fourth SDG 'Responsible consumption and production'. Participants could then choose: "Do you want Pensioenfonds Detailhandel to leave out the fourth sustainable development goal 'Responsible consumption and production'?". Answer options were 'Yes, leave it out', 'No, do not leave it out', and 'I have no opinion regarding this matter'. Real and hypothetical refers to whether answering the question "Do you want Pensioenfonds Detailhandel to add (leave out) the fourth sustainable development goal 'Responsible consumption and production'?" was consequential or not. Words in parentheses refer to the different status quo treatments. In the hypothetical treatment, choices were nonconsequential. In the real treatment, choices were guaranteed to be implemented by the pension fund if more than $50 \%$ of respondents would choose in favor of three, respectively four SDGs. For definitions of the other variables, see Table A.1. Significance levels show the difference from one and are indicated by *** $\mathrm{p}<0.01,{ }^{* *} \mathrm{p}<0.05,{ }^{*} \mathrm{p}<0.1$.

\begin{tabular}{|c|c|c|c|c|c|c|}
\hline & \multicolumn{2}{|c|}{ (1) } & \multicolumn{2}{|c|}{$(2)$} & \multicolumn{2}{|c|}{$(3)$} \\
\hline & 4 SDGs & No opinion & 4 SDGs & No opinion & 4 SDGs & No opinion \\
\hline \multicolumn{7}{|l|}{ Preferences } \\
\hline Social preferences (std) & & & & & $\begin{array}{c}1.5906^{* * *} \\
(0.1108)\end{array}$ & $\begin{array}{c}0.9848 \\
(0.0791)\end{array}$ \\
\hline \multicolumn{7}{|l|}{ Treatment effects } \\
\hline 4 SDG default & $\begin{array}{c}1.0617 \\
(0.1248)\end{array}$ & $\begin{array}{c}0.9366 \\
(0.1233)\end{array}$ & & & & \\
\hline 3 SDG default & & & 0.8026 & 1.0703 & 0.9052 & 1.2626 \\
\hline \& Hypothetical & & & $(0.1326)$ & $(0.1965)$ & $(0.1852)$ & $(0.2981)$ \\
\hline 4 SDG default & & & 0.8013 & 0.7646 & 1.0089 & 0.7844 \\
\hline \& Real & & & $(0.1286)$ & $(0.1401)$ & $(0.2035)$ & $(0.1902)$ \\
\hline 4 SDG default & & & 1.1792 & 1.2671 & $1.4264^{*}$ & 1.4921 \\
\hline \& Hypothetical & & & $(0.2054)$ & $(0.2451)$ & $(0.3035)$ & $(0.3666)$ \\
\hline Constant & $6.3118^{* * *}$ & $2.3176^{* * *}$ & $7.0119^{* * *}$ & $2.2381^{* * *}$ & $11.8750^{* * *}$ & $3.5013^{* * *}$ \\
\hline & $(0.5210)$ & $(0.2127)$ & $(0.8178)$ & $(0.2937)$ & $(4.0921)$ & $(1.3857)$ \\
\hline Observations & 3,256 & 3,256 & 3,256 & 3,256 & 2,383 & 2,383 \\
\hline Financial beliefs & No & No & No & No & Yes & Yes \\
\hline Demographics & No & No & No & No & Yes & Yes \\
\hline Financial background & No & No & No & No & Yes & Yes \\
\hline
\end{tabular}

On the other side, voters of parties like the Volkspartij voor Vrijheid en Democratie (VVD) or the Partij voor de Vrijheid (PVV) with a sustainability score of zero show one of the lowest acceptance rates for four SDGS. Nevertheless, across voters for all political parties more than $50 \%$ choose four SDGs (except for the party 'Forum voor Democratie'). Even among those who report to not have voted in the last national elections, $61.7 \%$ is in favor of four SDGs. Among those who do not state the party they voted for, the majority of $66.9 \%$ chose four SDGs.

The first specification in Table 4 shows that a respondent who voted for a party with a one standard deviation stronger preference for sustainable policies is $57.9 \%$ more likely to also choose the more sustainable option in our experiment. When we include control variables 
in specification (2), the effect size slightly decreases to $41.1 \%$ but stays highly significant. These results show the external validity of the support for four sustainable development goals. Participants took their choice seriously and chose more or less sustainability in line with how they evaluated political parties on sustainability in the last national election. Remarkably, even when we control for participants' preferences for sustainable policies, the effect size of social preferences barely changes compared to Tables 2 and 3. This underlines the importance of strong social preferences as explanation for the choice to invest more sustainably.

Result 5: Respondents who voted for a party which cares for sustainability are more likely to expand sustainable investing. This finding provides external validity consistent with a preference-based explanation for sustainable investments.

\subsection{Confusion and misunderstanding do not explain our results}

The absence of a hypothetical gap could be explained by respondents being confused or lacking information. We address this by re-analyzing our results, excluding: (1) Respondents who started to vote, but dropped out of the survey before finishing; (2) Respondents who did not understand the treatment and failed our manipulation check; (3) Respondents who report that they would have liked to receive more information before deciding on whether to choose three or four SDGs The manipulation check question was exactly the same for respondents in the hypothetical and in the real treatment and helps us to identify whether respondents understood the consequentiality of their choice. It looked as follows for the 3 SDG (4 SDG) default:

"If a majority chooses 'Yes, add' ('Yes, leave it out'), Pensioenfonds Detailhandel...

a. guarantees to add (leave out) 'Sustainable consumption and production' to (of) its socially responsible investment policy as the fourth Sustainable Development Goal. The Board of Pensioenfonds Detailhandel has decided to implement the outcome of this vote.

b. cannot guarantee that it will add (leave out) 'Sustainable consumption and production' to (of) its socially responsible investment policy as the fourth Sustainable Development Goal but may include the results of the survey in its choice."

We successively exclude each of the three types. The results are presented in Figure 4. The first bar represents the choice distribution of all participants, without exclusion. The second bar shows the choice distribution when respondents are excluded who did not complete the survey. The dropout rates between the real (26.9\%) and the hypothetical treatment (23.8\%; $\mathrm{p}$-value $=0.0433)$ are statistically different. Yet, the effect size of 3.1 percentage points is small, and the difference is likely to be significant because of our large sample size. The third bar shows the choice distribution excluding participants who did not understand the treatment they were in. This is the case for $14.0 \%$ in the real and $11.9 \%$ in the hypothetical treatment $(\mathrm{p}$-value $=0.0698)$. The fourth bar shows the distribution of choices excluding participants who 


\section{TABLE 4 - The effect of voting behavior on sustainable investing.}

This table presents relative-risk ratios of a multinomial logit regression where the dependent variable takes on three values for the choices '3 SDGs', '4 SDGs', and 'I have no opinion regarding this matter'. Baseline are respondents who chose three SDGs. For summary statistics, see Table A.2. Social preferences are elicited by asking respondents to rate the question "How willing are you to give to good causes without expecting anything in return?" on a 10-point Likert scale from completely unwilling to completely willing (see Falk et al. 2016). Preferences for sustainable policies is a score which is constructed by evaluating Dutch parties on their stance on sustainability using the official voting guide for the 2017 Dutch national elections (https: //tweedekamer2017.stemwijzer.nl). Five of the 30 questions shown deal with sustainable issues. All questions are posed such that they can be answered with 'agree', 'disagree', or 'neither of the two'. A party receives one point for each question for which they choose the more sustainable option. If a party chooses 'neither of the two', it receives half a point (see Table A.5). 3 SDG default and 4 SDG default refer to two different status quo treatments to which participants were randomly assigned. In the $3 S D G$ default, participants were told that the pension fund currently focuses on three SDGs. Participants were introduced to the fourth SDG 'Responsible consumption and production' and could choose: "Do you want Pensioenfonds Detailhandel to add the fourth sustainable development goal 'Responsible consumption and production'?". Answer options were 'Yes, add', 'No, do not add', and 'I have no opinion regarding this matter'. In the 4 SDG default treatment, it was communicated that the pension fund's future policy will include a fourth SDG 'Responsible consumption and production'. Participants could then choose: "Do you want Pensioenfonds Detailhandel to leave out the fourth sustainable development goal 'Responsible consumption and production'?". Answer options were 'Yes, leave it out', 'No, do not leave it out', and 'I have no opinion regarding this matter'. Real and hypothetical refers to whether answering the question "Do you want Pensioenfonds Detailhandel to add (leave out) the fourth sustainable development goal 'Responsible consumption and production'?" was consequential or not. Words in parentheses refer to the different status quo treatments. In the hypothetical treatment, choices were nonconsequential. In the real treatment, choices were guaranteed to be implemented by the pension fund if more than $50 \%$ of respondents would choose in favor of three, respectively four SDGs. For definitions of the other variables, see Table A.1. Significance levels show the difference from one and are indicated by $* * * \mathrm{p}<0.01$, $* * \mathrm{p}<0.05, * \mathrm{p}<0.1$.

(1)

(2)

\begin{tabular}{|c|c|c|c|c|}
\hline & 4 SDGs & No opinion & 4 SDGs & No opinion \\
\hline \multicolumn{5}{|l|}{ Preferences } \\
\hline Social preferences (std) & & & $\begin{array}{c}1.5822^{* * *} \\
(0.1563)\end{array}$ & $\begin{array}{c}1.0068 \\
(0.1173)\end{array}$ \\
\hline $\begin{array}{l}\text { Preferences for } \\
\quad \text { sustainable policies (std) }\end{array}$ & $\begin{array}{c}1.5792^{* * *} \\
(0.1467)\end{array}$ & $\begin{array}{c}1.0324 \\
(0.1168)\end{array}$ & $\begin{array}{c}1.4011^{* * *} \\
(0.1460)\end{array}$ & $\begin{array}{c}0.9328 \\
(0.1174)\end{array}$ \\
\hline \multicolumn{5}{|l|}{ Treatment effects } \\
\hline 3 SDG default & & & 1.2239 & 1.2980 \\
\hline \& Hypothetical & & & $(0.3315)$ & $(0.4160)$ \\
\hline 4 SDG default & & & 1.2070 & 0.8061 \\
\hline \& Real & & & $(0.3224)$ & $(0.2654)$ \\
\hline 4 SDG default & & & $1.7303^{*}$ & 1.4153 \\
\hline \& Hypothetical & & & $(0.4876)$ & $(0.4740)$ \\
\hline \multirow[t]{2}{*}{ Constant } & $8.8277^{* * *}$ & $1.5123^{* * *}$ & $23.2743^{* * *}$ & $4.0121^{* *}$ \\
\hline & $(0.8370)$ & $(0.1753)$ & $(12.0556)$ & $(2.4765)$ \\
\hline Observations & 1,507 & 1,507 & 1,425 & 1,425 \\
\hline Financial beliefs & No & No & Yes & Yes \\
\hline Demographics & No & No & Yes & Yes \\
\hline Financial background & No & No & Yes & Yes \\
\hline
\end{tabular}

wanted more information for their decision. There is no difference between the real and the hypothetical treatment with $33.5 \%$ and $33.2 \%$ respectively (p-value $=0.8580$ ). Importantly, the support for four SDGs is unaffected by either of the exclusion criteria. 
Result 6: Neither dropouts, confusion, nor a lack of information affect our results. There is always a clear majority supporting more sustainable investments

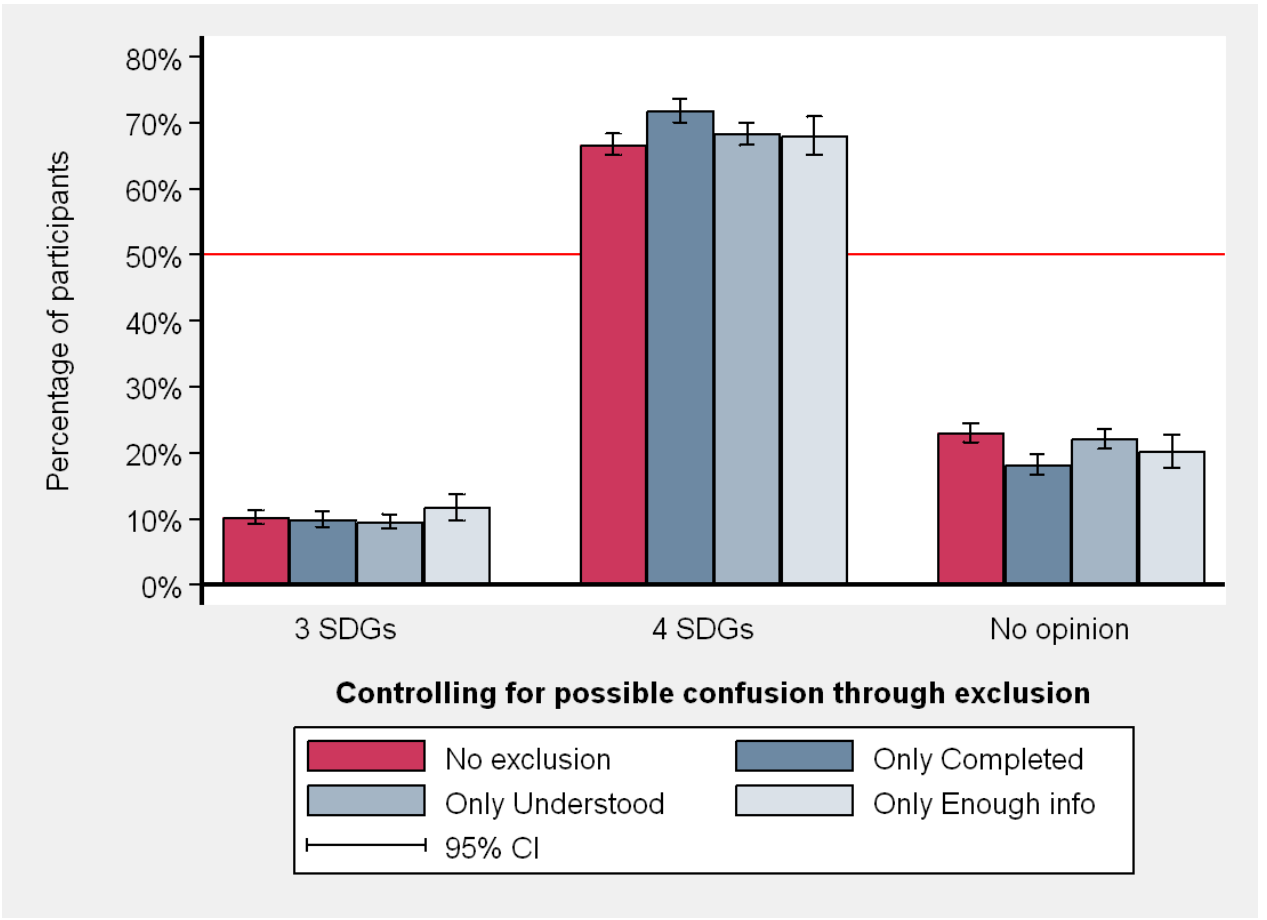

\section{FIgURE 4 - Controlling for possible confusion.}

The graph presents the distribution of all respondents (leftmost bar) and of three restricted subsamples separately regarding the following question: "Do you want Pensioenfonds Detailhandel to add (leave out) the fourth sustainable development goal 'Responsible consumption and production'?". Answer options were 'Yes, add (leave it out)', 'No, do not add (leave it out)', and 'I have no opinion regarding this matter'. Words in parentheses refer to the different status quo treatments which are looked at jointly here. In addition, the real and hypothetical treatments are looked at jointly. The second bar from the left (dark blue) presents the distribution of choices where respondents are excluded who dropped out of the survey after giving a choice on sustainable investing but before the end of the survey. The second bar from the right (medium blue) presents the distribution of choices where respondents are excluded wrongly answered the control question "If a majority chooses 'yes, add' ('no, leave it out'), a. Pensioenfonds Detailhandel guarantees to add (leave out) the fourth SDG; b. Pensioenfonds Detailhandel cannot guarantee that it will add (leave out) the fourth SDG, but may include the results of the survey in its choice." The rightmost bar (light blue) presents the distribution of choices where respondents are excluded who report that they would have liked to receive more information before deciding on whether to choose three or four SDGs. Error bars present $95 \%$ confidence intervals. Non-overlapping error bars indicate a statistically significant difference at the $5 \%$ level between the treatments real and hypothetical within each answer category.

\section{$5 \quad$ Additional findings}

\subsection{Social signaling}

Grimm (2010) finds that people often give socially desirable answers in a prosocial context. Paulhus (1984) defines social desirability as consisting of two components, self-deception and impression management. Impression management is also referred to as 'other-deception' and refers to managing the impression that others have of oneself. Socially desirable answering can be explained by the desire for social esteem and a positive self-image (see e.g. Bénabou and 
Tirole 2006; Ellingsen and Johannesson 2008; Tonin and Vlassopoulos 2013) and is especially attractive in hypothetical situations (e.g. Lusk and Norwood 2009; Norwood and Lusk 2011; Klink and Langen 2015). The fact that we do not find a hypothetical gap suggests that these reputational concerns do not play a major role among respondents.

We are unaware of a test of social desirability which would have been short enough to fit our survey. ${ }^{21}$. We therefore decided to focus on impression management and specifically test for social signaling. We ask respondents to rate the question "How likely is it that you will talk to your friends about this survey?" on a 10-point Likert scale from 1-very unlikely to 10 - very likely. The question is a modification of the social signaling question asked in Riedl and Smeets (2017) who find that sustainable investors talk more about their investments than conventional investors to signal their prosocial behavior. We especially expect respondents in the hypothetical treatment to be more likely to choose four SDGs if they show a bigger desire for social signaling. We therefore specifically look at subjects with an above-median social signaling desire (ratings of 3 and higher, $55.1 \%$ of the sample).

The results of testing for social signaling are presented in Figure A.2. If socially desirable answering were the driver to choose four SDGs, we should observe a hypothetical gap among those with a higher desire for social signaling. This is clearly not the case, as $75.8 \%$ of those in the hypothetical and $78.3 \%$ of those in the real treatment chose four SDGs (p-value $=0.2833$ ). Also, the percentage of those in favor if three SDGs (Hypothetical: 7.7\% vs Real: 9.7\%; pvalue $=0.2131$ ) does not differ across treatment groups. We only find a small difference between treatment groups for those with no opinion (Hypothetical: 16.4\% vs Real: 12.0\%; p-value = 0.0210). Thus, we find no hypothetical gap, even for people who are more likely to engage in social signaling.

\subsection{Pivotal voting}

There is a possibility that subjects in our experiment did not perceive their choice to be consequential. They might believe that their vote is unlikely to be pivotal. In that case, the real choice could simply be perceived as a hypothetical choice, which in turn could explain the large support for more sustainable investments and the absence of a hypothetical gap. Several aspects render it unlikely that this potential concern is driving our results.

First, voting theory shows that the use of a voting mechanism with a simple majority rule is incentive-compatible if the choice is binary, consequential, and if subjects care about the outcome (Cummings et al., 1997; Harrison, 2006a). The first two conditions are met as part of the experimental setup. Further, we can expect that the third condition is met by the fact that people's pension money is at stake. Thus, the choices selected by our participants maximize their personal utility function which implies that they report their preferences honestly.

\footnotetext{
${ }^{21}$ Multi-item scales for social desirability include Crowne and Marlowe (1960); Reynolds (1982), or Stöber (2001) These comprise at least eleven survey questions, which was too long to fit our survey.
} 
Second, the paradox of voting predicts that rational people do not vote as their expected benefits of casting the pivotal vote are lower than their expected costs (Downs, 1957). For example, Mulligan and Hunter (2003) find that only one of every 89,000 votes casted in U.S. Congressional elections, and one of 15,000 in state legislator elections were pivotal ${ }^{22}$. Nevertheless, turnout rates in political elections are usually quite high, which makes it at least difficult to justify that voters do not care about their vote when it is unlikely to be pivotal.

Even though theory and field evidence suggest that people take voting seriously, it is possible that in our experiment this was not the case. Third, we therefore distinguish between participants who expected to be more pivotal and those who expected to be less pivotal. If participants only supported more sustainable investments when they perceived their vote not to be pivotal, this would cast doubt on our finding that a majority prefers more sustainable investments. Also, if people only voted for more sustainable investments because they felt they were not pivotal, we would observe a hypothetical gap for participants who expected to be more pivotal. We tackle this concern in two different ways. First, we asked participants to estimate the percentage of participants who would choose three SDGs, four SDGs, or opt for 'no opinion'.23 Subjects who predicted that the share of those in favor of four SDGs is close to $50 \%$ should perceive their vote to be more pivotal than subjects with a prediction far away from 50\%. Following the just outlined expectation, we would expect a hypothetical gap to arise for subjects with a prediction close to $50 \%$. We define "pivotal" voters as those who predict the share of respondents choosing four SDGs to be between $40 \%$ and $60 \%$. This leaves us with 458 "pivotal" subjects in the real and 454 in the hypothetical treatment $(32.0 \%$ of the entire sample). We find no hypothetical gap as $73.6 \%$ of subjects in the real and $72.9 \%$ in the hypothetical treatment chose four SDGs $\left(\mathrm{p}\right.$-value =0.8186). ${ }^{24}$ Second, we asked subjects to estimate how many of the $25,000^{25}$ invited people would participate in the experiment. The median estimate was 10,000 participants. We define a 'pivotal' voter as someone who estimates that less than 10,000 would participate (meaning that the voter has a relatively higher probability to be pivotal). This leaves us with 586 "pivotal" subjects in the real and 605 in the hypothetical treatment. Again, we do not find a hypothetical gap as $72.5 \%$ in the real and $71.4 \%$ in the hypothetical treatment choose four SDGs ( $\mathrm{p}$-value $=0.6672) .{ }^{26}$

As additional check, we look at the two above-mentioned definitions of a "pivotal" voter jointly. There are 192 subjects in the real and 205 subjects in the hypothetical treatment who predict the share of respondents choosing four SDGs to be between $40 \%$ and $60 \%$ while at

$\overline{{ }^{22}}$ A pivotal vote in this case means that the candidate of that specific election tied for first or won by a single vote.

${ }^{23}$ Predictions of respondents in the real and in the hypothetical treatment are treated jointly as they do not differ.

24 This finding is robust to altering the definition of a "pivotal" voter. We also do not find a hypothetical gap when we look at those who predict the share of respondents choosing four SDGs to be between $45 \%$ and $55 \%$ as well as between $35 \%$ and $65 \%$.

${ }^{25}$ We gave 25,000 as reference point as one half of the 50,000 invited members was allocated to the real choice treatment and the other half to the hypothetical choice treatment.

26 This finding is robust to altering the definition of a "pivotal" voter. We also do not find a hypothetical gap when we look at those who estimate that less than 8,000 (bottom 45\%) as well as less than 11,000 (bottom $65 \%$ ) would participate. 
the same time estimating less than 10,000 would participate in the survey. We again find no hypothetical gap (Percentage choosing four SDGs: Real 71.9\% vs Hypothetical 75.6\%; p-value $=0.3990)$.

Taken together, we can rule out that participants support more sustainable investments, because they think that their vote is not pivotal.

\subsection{Exclusion of non-sustainable companies}

Investing according to the SDGs offers different approaches. While our question on adding a fourth SDG focused on engagement, we also elicited participants' preferences for exclusion policies. We told participants that exclusion means that the pension fund will refrain from investing in non-sustainable companies. It was explicitly mentioned that the questions on the exclusion policy in this part of the survey were of hypothetical nature but that the pension fund is interested in learning about their opinion. Thus, respondents were no longer grouped into real and hypothetical treatments. Specifically, respondents were asked to choose from a list of topics. Multiple answers were allowed. Each item they could choose indicated that they would want to exclude companies which relate to this item. For example, respondents could state that they want their pension fund to exclude companies which produce tobacco or alcohol (for a full list, see Table A.1). Respondents could also choose to not exclude any company.

Table A.7 presents the answer distribution of the exclusion question. Column (1) shows the average answer over all respondents. In columns (2) to (4), respondents are split into the three answer categories '4 SDGs', '3 SDGs', and 'no opinion' which correspond to whether they chose three or four SDGs or did not have an opinion. It shows that the willingness to exclude companies is in general high. Across all three answer categories, respondents chose to exclude companies on seven of nine items with more than $50 \%$. We observe the highest rates of approval for exclusion due to corruption (86.9\%), child labor (85.8\%), and human rights violations $(85.3 \%)$.

Importantly, this table also shows that people do not simply choose more sustainable investments whenever given a choice. Only a minority is in favor of excluding companies that produce alcohol (17.4\%) and tobacco (44.2\%). Even among those who chose four SDGs, those numbers are with $18.6 \%$ and $47.5 \%$ clearly below the threshold of $50 \%$. Given the strong pressure that is currently being put on pension funds to divest from tobacco, it is remarkable to see that these pension fund members decide to still keep their tobacco investments. Participants take a strong stance against excluding tobacco and alcohol companies, even in a hypothetical setting, where the costs of giving socially desirable answers are low.

\section{Conclusion}

The United Nations Sustainable Development Goals (SDGs) created societal and political pressure for companies and investors to promote sustainability. How much are individuals willing to support investments based on the SDGs? Are they willing to put their pension money on 
the table to invest sustainably? We ran an experiment with a pension fund which granted its members a real vote. We find that $66.7 \%$ of the participants are in favor of investing their pension savings more sustainably which is driven by strong social preferences. We can rule out financial beliefs, confusion, a lack of information, and social concerns as explanation for the large support of sustainable investing.

Social preferences have a significant influence on many economic decisions. They are a key to understanding what incentivizes people (Fehr and Fischbacher, 2002; Bandiera et al., 2005), can decrease free riding problems (Bandiera et al., 2005), and explain why people are willing to sacrifice resources to increase social welfare (Fehr and Schmidt, 1999; Bolton and Ockenfels, 2000; Charness and Rabin, 2002). While European investment managers elicit clients' risk preferences, most of them ignore social preferences (EUROSIF, 2016, p. 82). This raises a simple question: Why the reluctance towards social preferences? While previous research shows the importance of social preferences for some investors, it has been hard for institutional investors to use these findings when deciding on behalf of their clients. For instance, Bollen (2007); Barber et al. (2018); Hong and Kostovetsky (2012) and Hartzmark and Sussman (2018) show that investors value sustainability. Yet, consider a pension fund manager: with aggregatelevel data, he will have trouble to identify the preferences for sustainable investments of his clients. And even with findings on the individual level, the pension fund manager would not know what to do. Take the findings of Riedl and Smeets (2017) who show that $16 \%$ of their sample holds a sustainable mutual fund. The pension fund manager could now say that the majority does not want to hold sustainable mutual funds. Case closed. Yet, Beshears et al. (2008) show that inertia often keeps people from acting according to their true preferences. Thus, fund managers have to elicit the social preferences of their clients themselves and act accordingly.

We offer a simple toolbox for institutional investors to cater to the social preferences of their clients. We demonstrate that individuals are indeed willing to put their pension savings on the table to promote sustainability, in both a hypothetical and real choice.

The absence of the hypothetical gap does not imply that all institutional investors can elicit true preferences for sustainable investments with hypothetical survey questions. Choices in our experiment were identical in the hypothetical and real treatment, because participants have strong social preferences. In other cases, social preferences might be weaker, and a hypothetical gap could arise. For example, in countries where people have weaker social preferences. Yet, importantly, our findings are not driven by specifically looking at people with strong preferences. As the Netherlands are known for their large share of assets invested sustainably (EUROSIF, 2016), it could be that the Dutch population just has particularly strong social preferences which drive sustainable investments and limit the generalizability of our findings. However, that is not the case. Falk et al. (2018), whose question on social preferences we used in our survey, study the global variation of social preferences. They find that the social preferences of the Dutch population are 0.19 standard deviations below world average. At the same time, Germany $(-0.05)$ and the UK $(+0.03)$ are close to the world average while the US $(+0.41)$ ranges clearly 
above. In other words, even though the Netherlands are one of the most sustainable investors in the world, they show below-average levels of social preferences. Given the even stronger social preferences in countries like the US, there is substantial growth potential for sustainable investments in these markets.

Outside of the investment industry, our proposed method can inform decision-makers who decide on behalf of others. Politicians could elicit social preferences to address key sustainable policy questions such as a ban on plastic bags or creating restricted zones in inner cities which cannot be accessed by cars. If politicians were to rely on real preferences, this could not only help to objectively make better decisions but also can create a wider public support for the outcome - even if it is costly. But for that to be true, politicians have to get real! 


\section{References}

Ajzen, I., Brown, T. C. and Carvajal, F. (2004). Explaining the discrepancy between intentions and actions: The case of hypothetical bias in contingent valuation. Personality and Social Psychology Bulletin, 30 (9), 1108-1121.

Almås, I., Cappelen, A. W. and Tungodden, B. (2016). Cutthroat capitalism versus cuddly socialism: Are americans more meritocratic and efficiency-seeking than scandinavians? Working paper.

Alserda, G., Dellaert, B., Swinkels, L. and Van der Lecq, S. (2016). Pension risk preferences. Netspar Industry Design Paper, 62.

Andreoni, J., RaO, J. M. and Trachtman, H. (2017). Avoiding the ask: A field experiment on altruism, empathy, and charitable giving. Journal of Political Economy, 125 (3), 625-653.

Bandiera, O., Barankay, I. and Rasul, I. (2005). Social preferences and the response to incentives: Evidence from personnel data. The Quarterly Journal of Economics, 120 (3), 917-962.

Barber, B. M., Morse, A. and Yasuda, A. (2018). Impact investing. Working paper.

BÉnabou, R. and Tirole, J. (2006). Incentives and prosocial behavior. American Economic Review, 96 (5), 1652-1678.

Berger, I. E. and Corbin, R. M. (1992). Perceived consumer effectiveness and faith in others as moderators of environmentally responsible behaviors. Journal of Public Policy $\&$ Marketing, pp. 79-89.

Beshears, J., Choi, J., Clayton, C., Harris, C., Laibson, D. and Madrian, B. (2014). Optimal illiquidity. Paper for the Retirement Research Consortium, September, 26.

-, Choi, J. J., Laibson, D. and Madrian, B. C. (2008). How are preferences revealed? Journal of Public Economics, 92 (8-9), 1787-1794.

Bialkowski, J. and Starks, L. T. (2016). Sri funds: Investor demand, exogenous shocks and esg profiles. Working paper.

Blake, J. (1999). Overcoming the 'value-action gap'in environmental policy: Tensions between national policy and local experience. Local Environment, 4 (3), 257-278.

Bollen, N. P. (2007). Mutual fund attributes and investor behavior. Journal of Financial and Quantitative Analysis, 42 (3), 683-708.

Bolton, G. E. and Katok, E. (1995). An experimental test for gender differences in beneficent behavior. Economics Letters, 48 (3-4), 287-292.

- and Ockenfels, A. (2000). Erc: A theory of equity, reciprocity, and competition. American Economic Review, 90 (1), 166-193.

Brown, T. C., Champ, P. A., Bishop, R. C. and McCollum, D. W. (1996). Which response format reveals the truth about donations to a public good? Land Economics, pp. $152-166$. 
Bullock, W., Imai, K. and Shapiro, J. N. (2011). Statistical analysis of endorsement experiments: Measuring support for militant groups in pakistan. Political Analysis, 19 (4), 363-384.

Carroll, G. D., Choi, J. J., Laibson, D., Madrian, B. C. and Metrick, A. (2009). Optimal defaults and active decisions. The Quarterly Journal of Economics, 124 (4), 16391674.

Carson, R., Groves, T., List, J. and Machina, M. (2006). Probabilistic influence and supplemental benefits: a field test of the two key assumptions behind using stated preferences. Unpublished manuscript, 2.

Carson, R. T. and Groves, T. (2007). Incentive and informational properties of preference questions. Environmental and Resource Economics, 37 (1), 181-210.

Champ, P. A. and Bishop, R. C. (2001). Donation payment mechanisms and contingent valuation: an empirical study of hypothetical bias. Environmental and Resource Economics, 19 (4), 383-402.

- - - Brown, T. C. and McCollum, D. W. (1997). Using donation mechanisms to value nonuse benefits from public goods. Journal of Environmental Economics and Management, 33 (2), 151-162.

Charness, G. and Gneezy, U. (2010). Portfolio choice and risk attitudes: An experiment. Economic Inquiry, 48 (1), 133-146.

- and RABIn, M. (2002). Understanding social preferences with simple tests. The Quarterly Journal of Economics, 117 (3), 817-869.

Cohn, A., Jessen, L., Klasjna, M. and Smeets, P. (2018). Distributional preferences of the top 5us. Working paper.

Croson, R. and Gneezy, U. (2009). Gender differences in preferences. Journal of Economic Literature, 47 (2), 448-74.

Crowne, D. P. and Marlowe, D. (1960). A new scale of social desirability independent of psychopathology. Journal of Consulting Psychology, 24 (4), 349.

Cummings, R. G., Elliott, S., Harrison, G. W. and Murphy, J. (1997). Are hypothetical referenda incentive compatible? Journal of Political Economy, 105 (3), 609-621.

-, Harrison, G. W. and Rutstrom, E. E. (1995). Homegrown values and hypothetical surveys: Is the dichotomous choice approach incentive-compatible? American Economic Review, 85 (1), 260.

— and TAYLOR, L. O. (1998). Does realism matter in contingent valuation surveys? Land Economics, pp. 203-215.

— and — (1999). Unbiased value estimates for environmental goods: a cheap talk design for the contingent valuation method. American Economic Review, 89 (3), 649-665.

De-Magistris, T., Gracia, A. and Nayga Jr, R. M. (2013). On the use of honesty priming tasks to mitigate hypothetical bias in choice experiments. American Journal of Agricultural Economics, 95 (5), 1136-1154. 
Della Vigna, S., List, J. A. and Malmendier, U. (2012). Testing for altruism and social pressure in charitable giving. The Quarterly Journal of Economics, 127 (1), 1-56.

Derwall, J., Guenster, N., Bauer, R. and Koedijk, K. (2005). The eco-efficiency premium puzzle. Financial Analysts Journal, pp. 51-63.

Donkers, B., Lourenço, C. and Dellaert, B. G. (2012). Measuring and debiasing consumer pension risk attitudes. Netspar panel paper, 28.

Downs, A. (1957). An economic theory of political action in a democracy. Journal of Political Economy, 65 (2), 135-150.

Eckel, C. C. and Grossman, P. J. (1998). Are women less selfish than men?: Evidence from dictator experiments. The Economic Journal, 108 (448), 726-735.

Edmans, A. (2011). Does the stock market fully value intangibles? employee satisfaction and equity prices. Journal of Financial Economics, 101 (3), 621-640.

Ellingsen, T. and Johannesson, M. (2008). Pride and prejudice: The human side of incentive theory. American Economic Review, 98 (3), 990-1008.

EllsBerG, D. (1961). Risk, ambiguity, and the savage axioms. The Quarterly Journal of Economics, pp. 643-669.

Ethier, R. G., Poe, G. L., Schulze, W. D. and Clark, J. (2000). A comparison of hypothetical phone and mail contingent valuation responses for green-pricing electricity programs. Land Economics, pp. 54-67.

EUROSIF (2016). European sri study 2016.

Falk, A., Becker, A., Dohmen, T., Enke, B., Huffman, D. and Sunde, U. (2018). Global evidence on economic preferences. The Quarterly Journal of Economics, 133 (4), 1645-1692.

- - - - - Huffman, D. and Sunde, U. (2016). The preference survey module: A validated instrument for measuring risk, time, and social preferences. Working paper.

Fehr, E. and Fischbacher, U. (2002). Why social preferences matter-the impact of nonselfish motives on competition, cooperation and incentives. The Economic Journal, 112 (478), C1-C33.

— and Schmidt, K. M. (1999). A theory of fairness, competition, and cooperation. The Quarterly Journal of Economics, 114 (3), 817-868.

Feldman, J., Miyamoto, J. and Loftus, E. F. (1999). Are actions regretted more than inactions? Organizational Behavior and Human Decision Processes, 78 (3), 232-255.

FeldmanHall, O., Mobbs, D., Evans, D., Hiscox, L., Navrady, L. and Dalgleish, T. (2012). What we say and what we do: the relationship between real and hypothetical moral choices. Cognition, 123 (3), 434-441.

Fisman, R., Jakiela, P. and Kariv, S. (2017). Distributional preferences and political behavior. Journal of Public Economics, 155, 1-10.

Fowler III, A. R. and Close, A. G. (2012). It ain't easy being green: Macro, meso, and micro green advertising agendas. Journal of Advertising, 41 (4), 119-132. 
Frey, B. S. and MeIER, S. (2004). Social comparisons and pro-social behavior: Testing" conditional cooperation" in a field experiment. American Economic Review, 94 (5), $1717-$ 1722.

Gingerich, D. W. (2010). Understanding off-the-books politics: Conducting inference on the determinants of sensitive behavior with randomized response surveys. Political Analysis, 18 (3), 349-380.

Gneezy, A., Gneezy, U., Nelson, L. D. and Brown, A. (2010). Shared social responsibility: A field experiment in pay-what-you-want pricing and charitable giving. Science, 329 (5989), 325-327.

Gneezy, U. and List, J. A. (2006). Putting behavioral economics to work: Testing for gift exchange in labor markets using field experiments. Econometrica, 74 (5), 1365-1384.

Goda, G. S., Levy, M. R., Manchester, C. F., Sojourner, A. and Tasoff, J. (2015). The role of time preferences and exponential-growth bias in retirement savings. Tech. rep., National Bureau of Economic Research.

Gracia, A., Loureiro, M. L. and Nayga Jr, R. M. (2011). Are valuations from nonhypothetical choice experiments different from those of experimental auctions? American Journal of Agricultural Economics, 93 (5), 1358-1373.

Grimm, P. (2010). Social desirability bias. Wiley International Encyclopedia of Marketing.

Güth, W., Schmidt, C. and Sutter, M. (2007). Bargaining outside the lab-a newspaper experiment of a three-person ultimatum game. The Economic Journal, 117 (518), 449-469.

Harrison, G. W. (2006a). Experimental evidence on alternative environmental valuation methods. Environmental and Resource Economics, 34 (1), 125-162.

- (2006b). Making choice studies incentive compatible. In Valuing environmental amenities using stated choice studies, Springer, pp. 67-110.

-, Harstad, R. M. and Rutström, E. E. (2004). Experimental methods and elicitation of values. Experimental Economics, 7 (2), 123-140.

- and Rutström, E. E. (2008). Experimental evidence on the existence of hypothetical bias in value elicitation methods. Handbook of Experimental Economics Results, 1, 752-767.

Hartzmark, S. M. and Sussman, A. B. (2018). Do investors value sustainability? a natural experiment examining ranking and fund flows. Working paper.

Hong, H. and KacPerczyK, M. (2009). The price of sin: The effects of social norms on markets. Journal of Financial Economics, 93 (1), 15-36.

- and Kostovetsky, L. (2012). Red and blue investing: Values and finance. Journal of Financial Economics, 103 (1), 1-19.

Jennings, P. L., Mitchell, M. S. and Hannah, S. T. (2015). The moral self: A review and integration of the literature. Journal of Organizational Behavior, 36 (S1), S104-S168.

John, L. K., Loewenstein, G. and Prelec, D. (2012). Measuring the prevalence of questionable research practices with incentives for truth telling. Psychological Science, 23 (5), $524-532$. 
JP Morgan (2018). Sustainable investing is moving mainstream.

Kahneman, D., Knetsch, J. L. and Thaler, R. H. (1991). Anomalies: The endowment effect, loss aversion, and status quo bias. Journal of Economic Perspectives, 5 (1), 193-206.

Kerschbamer, R. and Müller, D. (2017). Social preferences and political attitudes: An online experiment on a large heterogeneous sample. Tech. rep.

Kessler, J. B., Milkman, K. L. and Zhang, C. Y. (2018). Getting the rich and powerful to give. Working paper.

Klink, J. and LAngen, N. (2015). Are animal welfare aspects of relevance in consumers' purchase decision? Proceedings in Food System Dynamics, pp. 328-346.

Kollmuss, A. and Agyeman, J. (2002). Mind the gap: why do people act environmentally and what are the barriers to pro-environmental behavior? Environmental Education Research, 8 (3), 239-260.

KrüGER, P. (2015). Corporate goodness and shareholder wealth. Journal of Financial Economics, 115 (2), 304-329.

Krüger, P., Sautner, Z. and Starks, L. T. (2018). The importance of climate risks for institutional investors. Working paper.

List, J. A. (2001). Do explicit warnings eliminate the hypothetical bias in elicitation procedures? evidence from field auctions for sportscards. American Economic Review, 91 (5), 1498-1507.

- (2006). The behavioralist meets the market: Measuring social preferences and reputation effects in actual transactions. Journal of Political Economy, 114 (1), 1-37.

- and Gallet, C. A. (2001). What experimental protocol influence disparities between actual and hypothetical stated values? Environmental and Resource Economics, 20 (3), 241-254.

- and Shogren, J. F. (1998a). Calibration of the difference between actual and hypothetical valuations in a field experiment. Journal of Economic Behavior $\&$ Organization, 37 (2), 193-205.

- and - (1998b). The deadweight loss of christmas: comment. The American Economic Review, 88 (5), 1350-1355.

- and - (2002). Calibration of willingness-to-accept. Journal of Environmental Economics and Management, 43 (2), 219-233.

Loomis, J., Bell, P., Cooney, H., Asmus, C. et al. (2009). A comparison of actual and hypothetical willingness to pay of parents and non-parents for protecting infant health: the case of nitrates in drinking water. Journal of Agricultural and Applied Economics, 41 (3), $697-712$.

Loomis, J. B. (2014). 2013 waea keynote address: Strategies for overcoming hypothetical bias in stated preference surveys. Journal of Agricultural and Resource Economics, pp. 34-46.

Lusk, J. L. and Norwood, F. B. (2009). Bridging the gap between laboratory experiments and naturally occurring markets: an inferred valuation method. Journal of Environmental Economics and Management, 58 (2), 236-250. 
MCKinsey (2017). From 'why' to 'why not': Sustainable investing as the new normal.

MukerJi, S. and TAllon, J.-M. (2001). Ambiguity aversion and incompleteness of financial markets. The Review of Economic Studies, 68 (4), 883-904.

Mulligan, C. B. and Hunter, C. G. (2003). The empirical frequency of a pivotal vote. Public Choice, 116 (1-2), 31-54.

Murphy, J. J., Allen, P. G., Stevens, T. H. and Weatherhead, D. (2005). A metaanalysis of hypothetical bias in stated preference valuation. Environmental and Resource Economics, 30 (3), 313-325.

Nicolle, A., Fleming, S. M., Bach, D. R., Driver, J. and Dolan, R. J. (2011). A regret-induced status quo bias. Journal of Neuroscience, 31 (9), 3320-3327.

Norwood, F. B. and Lusk, J. L. (2011). Social desirability bias in real, hypothetical, and inferred valuation experiments. American Journal of Agricultural Economics, 93 (2), 528534.

O’Donoghue, T. and Rabin, M. (1998). Procrastination in preparing for retirement. University of California-Berkeley Working Paper.

Osman, M. and Wiegmann, A. (2017). Explaining moral behavior. Experimental Psychology.

Paulhus, D. L. (1984). Two-component models of socially desirable responding. Journal of Personality and Social Psychology, 46 (3), 598.

Renneboog, L., Ter Horst, J. and Zhang, C. (2008). Socially responsible investments: Institutional aspects, performance, and investor behavior. Journal of Banking \&5 Finance, 32 (9), 1723-1742.

Reynolds, W. M. (1982). Development of reliable and valid short forms of the marlowecrowne social desirability scale. Journal of Clinical Psychology, 38 (1), 119-125.

Rhodes, R. E. and De Bruijn, G.-J. (2013). How big is the physical activity intentionbehaviour gap? a meta-analysis using the action control framework. British Journal of Health Psychology, 18 (2), 296-309.

Riedl, A. and Smeets, P. (2017). Why do investors hold socially responsible mutual funds? The Journal of Finance, 72 (6), 2505-2550.

Salomon, E., Preston, J. L. and Tannenbaum, M. B. (2017). Climate change helplessness and the (de) moralization of individual energy behavior. Journal of Experimental Psychology: Applied, 23 (1), 15.

Samuelson, W. and Zeckhauser, R. (1988). Status quo bias in decision making. Journal of Risk and Uncertainty, 1 (1), 7-59.

Stöвer, J. (2001). The social desirability scale-17 (sds-17): Convergent validity, discriminant validity, and relationship with age. European Journal of Psychological Assessment, 17 (3), 222 .

Terlau, W. and Hirsch, D. (2015). Sustainable consumption and the attitude-behaviourgap phenomenon-causes and measurements towards a sustainable development. International Journal on Food System Dynamics, 6 (3), 159-174. 
Tonin, M. and Vlassopoulos, M. (2013). Experimental evidence of self-image concerns as motivation for giving. Journal of Economic Behavior \& Organization, 90, 19-27.

Tversky, A. and Kahneman, D. (1991). Loss aversion in riskless choice: A referencedependent model. The Quarterly Journal of Economics, 106 (4), 1039-1061.

Vermeir, I. and Verbeke, W. (2006). Sustainable food consumption: Exploring the consumer "attitude-behavioral intention" gap. Journal of Agricultural and Environmental ethics, 19 (2), 169-194.

WiLlis Tower Watson (2018). Global pension assets study 2018. 


\section{Appendix}

\section{A Tables}

\section{TABLE A.1 - Variable definition}

\begin{tabular}{l} 
Variable \\
\hline \hline Preferences \\
Social preferences \\
\\
Preferences for sustainable poli- \\
cies
\end{tabular}

\section{Social concerns}

Social signaling

\section{Financial beliefs}

Expected returns with 4 SDGs

Lower returns with 4 SDGs

Equal returns with 3 or 4 SDGs

Higher returns with 4 SDGs

Do not know

Willingness to pay

Accept lower returns

\section{Treatments}

Real

Hypothetical

\section{Description}

The participant's response to the question "How willing are you to give to good causes without expecting anything in return?" (1 completely unwilling, ..., 10 completely willing; Falk et al. 2016). Preference for sustainable policies is a score which is constructed by evaluating Dutch parties on their stance on sustainability using the official voting guide for the 2017 Dutch national elections (https://tweedekamer2017.stemwijzer.nl). Five of the 30 questions shown deal with sustainable issues. All questions are posed such that they can be answered with 'agree', 'disagree', or 'neither of the two'. A party receives one point for each question for which they choose the more sustainable option. If a party chooses 'neither of the two', it receives half a point.

The participant's response to the question "How likely is it that you will talk to your friends about this survey?" (1 very unlikely, ..., 10 very likely; adaption from Riedl and Smeets 2017).

The participant's response to the question "When do you think the investment return is highest?" Answer options: 'It is highest with 3 SDGs', 'The return is equally high with 3 or 4 SDGs', 'It is highest with 4 SDGs', and 'I do not know'.

Dummy variable equal to one if the participant believes that the returns is highest with three SDGs.

Dummy variable equal to one if the participant believes that the returns is equally high with three or four SDGs.

Dummy variable equal to one if the participant believes that the returns is highest with four SDGs.

Dummy variable equal to one if the participant reports to not know when the return is the highest.

The participant's response to the question "Do you want Pensioenfonds Detailhandel to opt for four SDGs if the return on investment would decrease?". Answer options: 'yes', 'no', and 'I do not know'

Participants in the real treatment were informed that the question "Do you want Pensioenfonds Detailhandel to add (leave out) the fourth sustainable development goal 'Responsible consumption and production'?" was consequential. Words in parentheses refer to the different status quo treatments. Choices were guaranteed to be implemented by the pension fund if more than $50 \%$ of respondents would choose in favor of three, respectively four SDGs.

Participants in the hypothetical treatment were informed that the question "Do you want Pensioenfonds Detailhandel to add (leave out) the fourth sustainable development goal 'Responsible consumption and production'?" was not consequential. Words in parentheses refer to the different status quo treatments. 
Table A.1-Continued

\begin{tabular}{l|l}
\hline Variable & \\
\hline \hline 3 SDG default &
\end{tabular}
iption

Participants in the 3 SDG default treatment were told that the pension fund currently focuses on three SDGs. Participants were introduced to the fourth SDG 'Responsible consumption and production' and could answer the question: "Do you want Pensioenfonds Detailhandel to add the fourth sustainable development goal 'Responsible consumption and production'?". Answer options: 'Yes, add', 'No, do not add', and 'I have no opinion regarding this matter'.

4 SDG default

\section{Demographics}

Female

Age

Highly educated

\section{Financial background} Low income

Middle income

High income

Do not report

\section{Comprehension}

Understodd treatment (Yes)

More information (Yes)

Exclusion policy
Participants in the 4 SDG default treatment were told that the pension fund's future policy will include a fourth SDG 'Responsible consumption and production'. Participants could then choose: "Do you want Pensioenfonds Detailhandel to leave out the fourth sustainable development goal 'Responsible consumption and production'?". Answer options: 'Yes, leave it out', 'No, do not leave it out', and 'I have no opinion regarding this matter'.

Dummy variable equal to one if the participant reports being a woman.

The participant's self-reported age.

Dummy variable equal to one if the participant reports having a university degree or a degree from a university of applied sciences.

Dummy variable equal to one if the participant's reported monthly net household income is below 2,500 euro.

Dummy variable equal to one if the participant's reported monthly net household income is between 2,500 euro and 4,000.

Dummy variable equal to one if the participant's reported monthly net household income is above 4,000 euro.

Dummy variable equal to one if the investor does not disclose his or her monthly net household income.

Dummy variable equal to one if the participant correctly answers the control question "If a majority chooses 'Yes, add' ('Yes, leave it out'), Pensioenfonds Detailhandel a. guarantees to add (leave out) 'Sustainable consumption and production' to (of) its socially responsible investment policy as the fourth Sustainable Development Goal. The Board of Pensioenfonds Detailhandel has decided to implement the outcome of this vote. b. cannot guarantee that it will add (leave out) 'Sustainable consumption and production' to (of) its socially responsible investment policy as the fourth Sustainable Development Goal but may include the results of the survey in its choice." Correct means answer 'a' if the participant is in the real choice treatment and ' $b$ ' if the participant is in the hypothetical choice treatment.

Dummy variable equal to one if the participant answers the question "Would you rather have received more information to make your choice on adding (leaving out) the fourth SDG?" with 'yes'. Answer options: 'Yes', 'No' 
Table A.1-Continued

\begin{tabular}{l|l}
\hline Variable & Description \\
\hline \hline Exclusion & The participant's response to the question "Pensioenfonds Detail- \\
& handel wants to know which companies it should exclude from its \\
& investments (multiple answers possible). Companies... a. pro- \\
& ducing tobacco; b. producing controversial weapons (e.g. clus- \\
& ter bombs and landmines); c. producing alcohol; d. producing \\
& weapons (weapons other than controversial weapons); e. violating \\
& human rights; f. using forced labor; g. having a bad influence on \\
& the environment; h. involving in corruption, extortion or bribery; \\
& i. allowing the use of child labor; j. I do not want to exclude \\
& companies."
\end{tabular}




\section{TABLE A.2 - Summary statistics.}

This table presents summary statistics for the survey respondents. Variable definitions are provided in Table A.1. Differences in the number of observations stem from the fact that not all participants in the experiments answered all survey questions.

\begin{tabular}{lcccr}
\hline & Mean & Median & Std Dev & Obs. \\
\hline Preferences & & & & \\
Social preferences (1-10) & 6.1 & 6 & 2.5 & 2,614 \\
Preferences for sustainable policies (0-5) & 2.5 & 4 & 2.1 & 1,558
\end{tabular}

\section{Financial beliefs}

Return expectation

Lower with 4 SDGs

$16.3 \%$

452

Equal with 3 or 4 SDGs

$24.7 \%$

684

Higher with 4 SDGs

$15.4 \%$

472

Do not know

$43.6 \%$

1,210

\section{Willingness to pay}

Accept lower returns

Yes

$42.3 \%$

965

No

$39.0 \%$

do not know

$18.7 \%$

891

428

\section{Demographics}

Female

$61.5 \%$

Age

46.4

50

1,631

Highly educated

$29.7 \%$

14.2

2,652

2,505

\section{Financial background}

Net income (monthly, per houshold)

Low income $(€ 0$ to $€ 2,500)$

$€ 2,868$

$35.3 \%$

$€ 2,750$

1,694

1,991

Middle income $(€ 2,500$ to $€ 4,000)$

$29.4 \%$

933

High income (above $€ 4,000$ )

$10.7 \%$

776

do not report

$24.7 \%$

282

653

\section{Comprehension}

Understood treatment (Yes) 
TABLE A.3 - Randomization check.

This table presents a randomization check on the key characteristics between respondents in the real and in the hypothetical treatment. Differences in the number of observations stem from the fact that not all participants in the experiments answered all survey questions. P-values are from $\chi^{2}$ tests $\left({ }^{a}\right)$, Kruskal-Wallis tests $\left({ }^{b}\right)$. Variable definitions are provided in Table A.1.

\begin{tabular}{|c|c|c|c|c|c|c|c|c|c|}
\hline & \multicolumn{4}{|c|}{ Real } & \multicolumn{4}{|c|}{ Hypothetical } & \multirow[t]{2}{*}{ p-value } \\
\hline & Mean & Median & Std Dev & Obs. & Mean & Median & Std Dev & Obs. & \\
\hline \multicolumn{10}{|l|}{ Demographics } \\
\hline Female & $60.8 \%$ & & & 1,295 & $62.4 \%$ & & & 1,269 & $0.416^{a}$ \\
\hline Age & 46.6 & 50 & 14.5 & 1,295 & 46.2 & 50 & 13.9 & 1,269 & $0.290^{b}$ \\
\hline Highly educated & $29.9 \%$ & & & 1,229 & $29.2 \%$ & & & 1,190 & $0.739^{a}$ \\
\hline \multicolumn{10}{|l|}{ Financial background } \\
\hline Net income (monthly, per houshold) & $€ 2,837$ & $€ 2,750$ & $€ 1,690$ & 969 & $€ 2,901$ & $€ 2,750$ & $€ 1,703$ & 949 & $0.321^{b}$ \\
\hline Low income $(€ 0$ to $€ 2,500)$ & $36.6 \%$ & & & 473 & $33.7 \%$ & & & 426 & $0.124^{a}$ \\
\hline Middle income $(€ 2,500$ to $€ 4,000)$ & $28.3 \%$ & & & 366 & $30.1 \%$ & & & 381 & $0.313^{a}$ \\
\hline High income (above $€ 4,000$ ) & $10.6 \%$ & & & 130 & $11.2 \%$ & & & 142 & $0.337^{a}$ \\
\hline do not report & $25.0 \%$ & & & 323 & $24.9 \%$ & & & 315 & $0.963^{a}$ \\
\hline \multicolumn{10}{|l|}{ Preferences } \\
\hline Social preferences $(1-10)$ & 6.1 & 7 & 2.5 & 1,280 & 6.1 & 6 & 2.4 & 1,249 & $0.631^{b}$ \\
\hline Preferences for sustainable policies $(0-5)$ & 2.5 & 4 & 2.1 & 772 & 2.5 & 4 & 2.1 & 735 & $0.463^{b}$ \\
\hline
\end{tabular}




\section{TABLE A.4 - Comparison of the official 2017 Dutch parliamentary election results to the reported voting behavior of respondents in our sample.}

This table presents the distribution of votes in the 2017 Dutch parliamentary elections within our sample and compares it to the official election results. 2,647 respondents answered the question "Did you vote in the last national parliamentary election?". Respondents were given the answer options 'Yes', 'No', and 'I do not want to say'. The last option was chosen by 139 respondents while 2,142 respondents reported to have voted. As a follow-up question, respondents were asked to name the party they voted for. They could also choose to keep this information private ('I do not want to say') which $562(26.2 \%)$ respondents did. The voting distribution of the remaining 1,580 respondents is reported below. The official 2017 parliamentary election results can be found online at https://www.verkiezingsuitslagen.nl/verkiezingen/detail/TK20170315.

\begin{tabular}{lcc}
\hline & $\begin{array}{c}\text { Reported } \\
\text { voting behavior }\end{array}$ & $\begin{array}{c}\text { Official 2017 } \\
\text { voter turnover }\end{array}$ \\
\hline Voted in 2017 & $85.4 \%$ & $81.6 \%$ \\
Voted for... & & \\
Volkspartij voor Vrijheid en Democratie (VVD) & $23.2 \%$ & $21.3 \%$ \\
Democraten 66 (D66) & $14.4 \%$ & $12.2 \%$ \\
GroenLinks & $14.0 \%$ & $9.1 \%$ \\
Christen-Democratisch Appèl (CDA) & $12.0 \%$ & $12.4 \%$ \\
SP (Socialistische Partij) & $7.5 \%$ & $9.1 \%$ \\
Partij voor de Vrijheid (PVV) & $5.3 \%$ & $13.1 \%$ \\
ChristenUnie & $5.0 \%$ & $3.4 \%$ \\
Partij van de Arbeid (P.v.d.A.) & $4.9 \%$ & $5.7 \%$ \\
Partij voor de Dieren & $4.6 \%$ & $3.2 \%$ \\
50PLUS & $2.8 \%$ & $3.1 \%$ \\
Staatkundig Gereformeerde Partij (SGP) & $2.3 \%$ & $2.1 \%$ \\
Forum voor Democratie & $2.1 \%$ & $1.8 \%$ \\
DENK & $0.4 \%$ & $2.1 \%$ \\
Other & $1.5 \%$ & $1.5 \%$ \\
\hline
\end{tabular}


TABLE A.5 - The preference for sustainable policies.

This table presents the preference for sustainable policies which is a score which is constructed by evaluating Dutch parties on their stance on sustainability using the official voting guide for the 2017 Dutch national elections (https://tweedekamer2017.stemwijzer.nl). Five of the 30 questions shown deal with sustainable issues. All questions are posed such that they can be answered with 'agree', 'disagree', or 'neither of the two'. A party receives one point for each question for which they choose the more sustainable option. If a party chooses 'neither of the two', it receives half a point. The score is calculated for each of the parties shown in Table A.4.

\begin{tabular}{|c|c|c|c|c|c|c|c|c|}
\hline & & VVD & PVV & CDA & D66 & GroenLinks & SP & PvdA \\
\hline Mileage tax & $\begin{array}{l}\text { The government must not tax the posses- } \\
\text { sion of the car, but the number of kilome- } \\
\text { ters driven. (agree }=1 \mathrm{pt} \text { ) }\end{array}$ & 0 & 0 & 0 & 1 & 1 & 1 & 1 \\
\hline Infrastructure & $\begin{array}{l}\text { More money needs to be spent on the con- } \\
\text { struction of new roads. (agree }=0 \mathrm{pts} \text { ) }\end{array}$ & 0 & 0 & 0 & 1 & 1 & 1 & 1 \\
\hline $\begin{array}{l}\text { Coal-fired } \\
\text { power stations }\end{array}$ & $\begin{array}{l}\text { All coal-fired power stations may remain } \\
\text { open for the time being. (agree }=0 \mathrm{pts} \text { ) }\end{array}$ & 0 & 0 & 0.5 & 1 & 1 & 1 & 1 \\
\hline $\begin{array}{l}\text { VAT rate for } \\
\text { meat }\end{array}$ & $\begin{array}{l}\text { The high VAT rate of } 21 \% \text { must be applied } \\
\text { to meat. (agree }=1 \mathrm{pt})\end{array}$ & 0 & 0 & 0 & 0 & 1 & 0 & 0 \\
\hline \multirow[t]{3}{*}{$\begin{array}{l}\text { Development } \\
\text { aid }\end{array}$} & $\begin{array}{l}\text { The Netherlands should spend more } \\
\text { money for the development of poor coun- } \\
\text { tries. (agree }=1 \mathrm{pt} \text { ) }\end{array}$ & 0 & 0 & 0 & 1 & 1 & 1 & 1 \\
\hline & Total & $\mathbf{0}$ & $\mathbf{0}$ & 0.5 & 4 & 5 & 4 & 4 \\
\hline & & $\begin{array}{l}\text { Christen- } \\
\text { Unie }\end{array}$ & $\begin{array}{l}\text { Partij voor } \\
\text { de Dieren }\end{array}$ & 50PLUS & SGP & DENK & $\begin{array}{l}\text { Forum voor } \\
\text { Democratie }\end{array}$ & \\
\hline Mileage tax & $\begin{array}{l}\text { The government must not tax the posses- } \\
\text { sion of the car, but the number of kilome- } \\
\text { ters driven. (agree }=1 \mathrm{pt} \text { ) }\end{array}$ & 1 & 1 & 0 & 1 & 1 & 1 & \\
\hline Infrastructure & $\begin{array}{l}\text { More money needs to be spent on the con- } \\
\text { struction of new roads. (agree }=0 \mathrm{pts} \text { ) }\end{array}$ & 1 & 1 & 1 & 0 & 1 & 0 & \\
\hline $\begin{array}{l}\text { Coal-fired } \\
\text { power stations }\end{array}$ & $\begin{array}{l}\text { All coal-fired power stations may remain } \\
\text { open for the time being. (agree }=0 \mathrm{pts} \text { ) }\end{array}$ & 1 & 1 & 1 & 0 & 1 & 0 & \\
\hline $\begin{array}{l}\text { VAT rate for } \\
\text { meat }\end{array}$ & $\begin{array}{l}\text { The high VAT rate of } 21 \% \text { must be applied } \\
\text { to meat. (agree }=1 \mathrm{pt} \text { ) }\end{array}$ & 0 & 1 & 0 & 0 & 0 & 0 & \\
\hline \multirow[t]{2}{*}{$\begin{array}{l}\text { Development } \\
\text { aid }\end{array}$} & $\begin{array}{l}\text { The Netherlands should spend more } \\
\text { money for the development of poor coun- } \\
\text { tries. (agree }=1 \mathrm{pt} \text { ) }\end{array}$ & 1 & 1 & 1 & 1 & 1 & 0 & \\
\hline & Total & 4 & 5 & 3 & 2 & 4 & 1 & \\
\hline
\end{tabular}




\section{TABLE A.6 - Voting behavior, preferences, and sustainable investing.}

This table presents the distribution of preferences and the choice on sustainable investing of respondents who are grouped according to their reported voting behavior in the Dutch national elections 2017. The reported voting behavior refers to the question "Did you vote in the last national parliamentary election?". Respondents were given the answer options 'Yes', 'No', and 'I do not want to say'. As a follow-up question, respondents were asked to name the party they voted for. They could also choose to keep this information private. Preferences for sustainable policies is a score which is constructed by evaluating Dutch parties on their stance on sustainability using the official voting guide for the 2017 Dutch national elections (https://tweedekamer2017.stemwijzer.nl). Five of the 30 questions shown deal with sustainable issues. All questions are posed such that they can be answered with 'agree', 'disagree', or 'neither of the two'. A party receives one point for each question for which they choose the more sustainable option. If a party chooses 'neither of the two', it receives half a point (see Table A.5). The distribution of choices '4 SDG' and ' 3 SDG' refers to the following question: "Do you want Pensioenfonds Detailhandel to add (leave out) the fourth sustainable development goal 'Responsible consumption and production'?" Answer options were 'Yes, add (leave it out)', 'No, do not add (leave it out)', and 'I have no opinion regarding this matter'. Words in parentheses refer to the different status quo treatments which are looked at jointly here as are real and hypothetical treatment.

\begin{tabular}{lccc}
\hline & $\begin{array}{c}\text { Preferences for } \\
\text { for sustainable } \\
\text { policies }\end{array}$ & $\begin{array}{c}\text { Percentage of } \\
\text { respondents } \\
\text { who chose }\end{array}$ \\
\hline GroenLinks & & 4 SDGs & 3 SDGs \\
Partij voor de Dieren & 5 & $89.8 \%$ & $5.1 \%$ \\
Democraten 66 (D66) & 5 & $88.9 \%$ & $2.8 \%$ \\
DENK & 4 & $85.0 \%$ & $8.2 \%$ \\
SP (Socialistische Partij) & 4 & $83.3 \%$ & $0.0 \%$ \\
Partij van de Arbeid (P.v.d.A.) & 4 & $78.5 \%$ & $6.0 \%$ \\
ChristenUnie & 4 & $77.9 \%$ & $6.5 \%$ \\
50PLUS & 4 & $76.0 \%$ & $9.3 \%$ \\
Staatkundig Gereformeerde Partij (SGP) & 3 & $70.7 \%$ & $7.3 \%$ \\
Forum voor Democratie & 2 & $72.2 \%$ & $8.3 \%$ \\
Christen-Democratisch Appèl (CDA) & 1 & $48.4 \%$ & $32.3 \%$ \\
Volkspartij voor Vrijheid en Democratie (VVD) & 0.5 & $74.3 \%$ & $6.4 \%$ \\
Partij voor de Vrijheid (PVV) & 0 & $71.1 \%$ & $13.8 \%$ \\
Other & 0 & $55.6 \%$ & $16.1 \%$ \\
Do not report & - & $60.8 \%$ & $17.4 \%$ \\
Did not vote & - & $66.9 \%$ & $11.9 \%$ \\
\hline
\end{tabular}




\section{TABLE A.7 - Approval ratings for various exclusion policies.}

This table compares the approval ratings of respondents regarding exclusion policies. Exclusion refers to the following question: "Pensioenfonds Detailhandel wants to know which companies it should exclude from its investments (multiple answers possible). Companies... a. producing tobacco; b. producing controversial weapons (e.g. cluster bombs and landmines); c. producing alcohol; d. producing weapons (weapons other than controversial weapons); e. violating human rights; f. using forced labor; g. having a bad influence on the environment; h. involving in corruption, extortion or bribery; i. allowing the use of child labor; j. I do not want to exclude companies." Respondents who choose to not exclude any company could not select any of the answer options 'a' through ' $\mathrm{i}$ '. Column (1) shows the average of all respondents who answered the exclusion question. The categorization of respondents in columns (2) to (4) is done according to how they answered the question: "Do you want Pensioenfonds Detailhandel to add (leave out) the fourth sustainable development goal 'Responsible consumption and production'?". Answer options were 'Yes, add (leave it out)', 'No, do not add (leave it out)', and 'I have no opinion regarding this matter'. Words in parentheses refer to the different status quo treatments which are looked at jointly here. Respondents are categorized into those who choose four SDGs, those who choose three SDGs, and those who report to have no opinion.

\begin{tabular}{lc|ccc}
\hline & All & 4 SDGs & 3 SDGs & No opinion \\
\hline Corruption & $86.9 \%$ & $90.9 \%$ & $77.0 \%$ & $76.0 \%$ \\
Child labor & $85.8 \%$ & $90.9 \%$ & $73.6 \%$ & $71.1 \%$ \\
Human rights violation & $85.3 \%$ & $90.8 \%$ & $69.3 \%$ & $71.5 \%$ \\
Forced labor & $83.0 \%$ & $87.8 \%$ & $70.5 \%$ & $70.5 \%$ \\
Controversial weapons & $79.4 \%$ & $84.7 \%$ & $69.7 \%$ & $63.2 \%$ \\
Bad influence on environment & $72.8 \%$ & $79.0 \%$ & $55.2 \%$ & $57.6 \%$ \\
Non-controversial weapons & $70.4 \%$ & $74.1 \%$ & $57.1 \%$ & $62.2 \%$ \\
Tobacco & $44.2 \%$ & $47.5 \%$ & $36.8 \%$ & $33.7 \%$ \\
Alcohol & $17.4 \%$ & $18.6 \%$ & $13.0 \%$ & $14.9 \%$ \\
No exclusion & $5.7 \%$ & $3.2 \%$ & $10.3 \%$ & $13.6 \%$ \\
\hline
\end{tabular}




\section{B Figures}

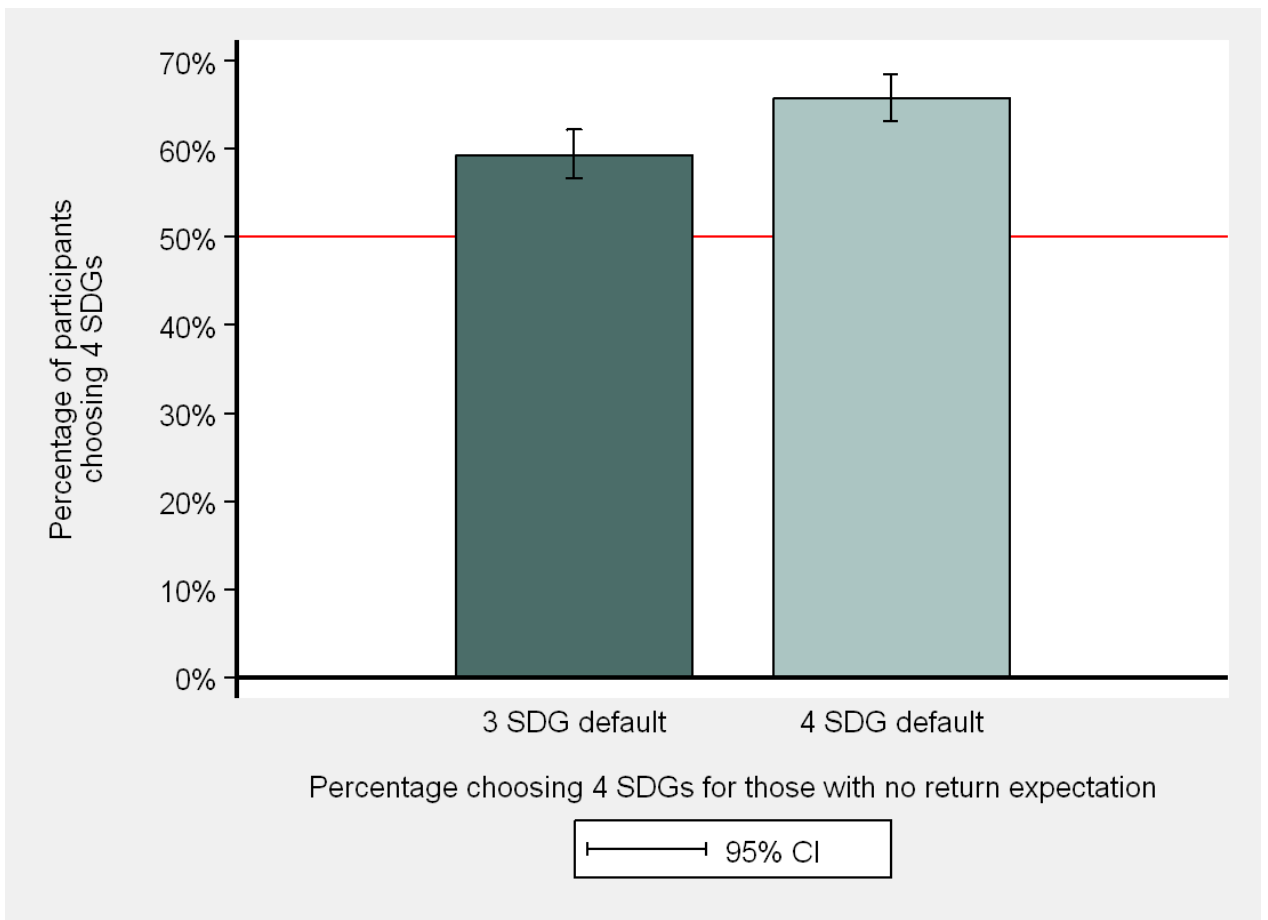

\section{Figure A.1 - Percentage choosing 4 SDGs if uncertain about return.}

The graph presents the percentage of participants choosing four SDGs if they answered 'I do not know' to the following question: "When do you think the investment return is highest?" Answer options were 'It is highest with 3 SDGs', 'The return is equally high with 3 or 4 SDGs', 'It is highest with 4 SDGs', and 'I do not know'. 3 SDG default and 4 SDG default refer to two different status quo treatments to which participants were randomly assigned. In the $3 S D G$ default, participants were told that the pension fund currently focuses on three SDGs. Participants were introduced to the fourth SDG 'Responsible consumption and production' and could choose: "Do you want Pensioenfonds Detailhandel to add the fourth sustainable development goal 'Responsible consumption and production'?". Answer options were 'Yes, add', 'No, do not add', and 'I have no opinion regarding this matter'. In the $4 S D G$ default treatment, it was communicated that the pension fund's future policy will include a fourth SDG 'Responsible consumption and production'. Participants could then choose: "Do you want Pensioenfonds Detailhandel to leave out the fourth sustainable development goal 'Responsible consumption and production'?". Answer options were 'Yes, leave it out', 'No, do not leave it out', and 'I have no opinion regarding this matter'. The real and hypothetical choice treatments are look at jointly. Error bars present $95 \%$ confidence intervals. Non-overlapping error bars indicate a statistically significant difference at the $5 \%$ level between the treatments real and hypothetical within each answer category. 


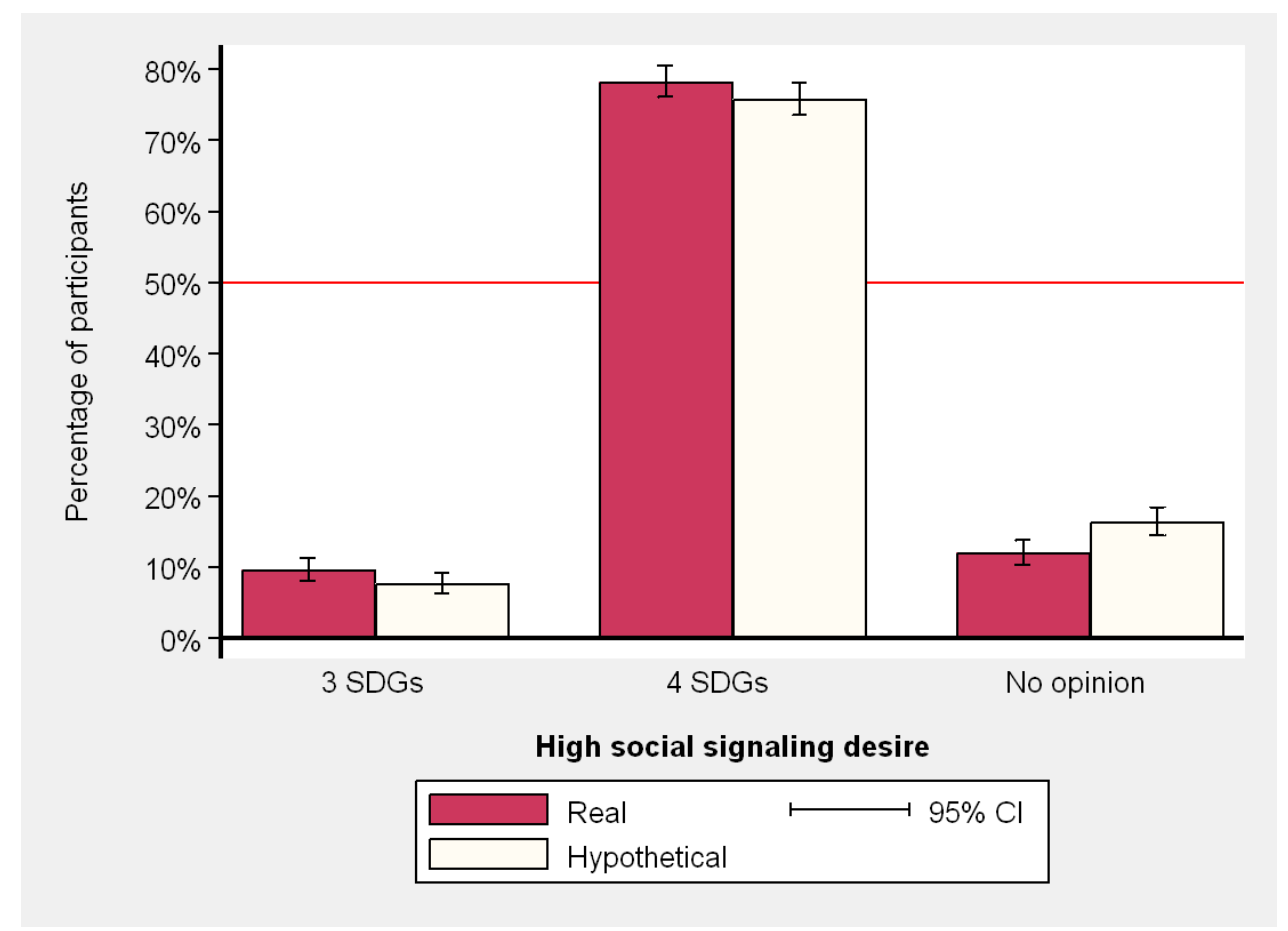

\section{FigurE A.2 - The effect of social signaling on sustainable investing.}

This graph presents the distribution of real and hypothetical choices for respondents with a high desire for social signaling. Social signaling is elicited by asking respondents to rate the question "How likely is it that you will talk to your friends about this survey?" on a 10-point Likert scale from very unlikely to very likely (see Riedl and Smeets, 2017). Respondents are reported to have a high desire for social signaling if they rated this question with a 3 or higher (55.1\% of the sample). The categories shown in the graph refer to the following question: "Do you want Pensioenfonds Detailhandel to add (leave out) the fourth sustainable development goal 'Responsible consumption and production'?". Answer options were 'Yes, add (leave it out)', 'No, do not add (leave it out)', and 'I have no opinion regarding this matter'. Words in parentheses refer to the different status quo treatments which are looked at jointly here. The graph presents the distribution of real and hypothetical choices separately, which refers to whether answering the above-stated question was consequential or not. In the hypothetical treatment, choices were nonconsequential. In the real treatment, choices were guaranteed to be implemented by the pension fund if more than $50 \%$ of respondents would choose in favor of three, respectively four SDGs. Error bars present 95\% confidence intervals. Non-overlapping error bars indicate a statistically significant difference at the $5 \%$ level between the treatments real and hypothetical within each answer category. 


\section{Appendix}

\section{A Survey}

\section{Welcome!}

Pensioenfonds Detailhandel invests your pension savings in a sustainable way. In doing so, Pensioenfonds Detailhandel strives to achieve continuous improvements.

[Real treatment] That is why Pensioenfonds Detailhandel has decided to ask you about our investment policy.

[Hypothetical treatment] Pensioenfonds Detailhandel is genuinely interested in your opinion on how we invest.

Of the people who participate in this survey, 25 randomly selected individuals will receive a VVV Gift Voucher worth 25 euros. Additionally, one randomly selected participant will receive a VVV Gift Voucher worth 250 euros.

You will be entered in the prize draw if you complete the whole survey. Maastricht University and Pensioenfonds Detailhandel guarantee that all payments will be made.

This survey takes around fifteen minutes to complete. Pensioenfonds Detailhandel will make the results available in Autumn.

Thank you in advance for your participation!

Yours sincerely, Maastricht University and Pensioenfonds Detailhandel.

\section{[Part 1]}

What is socially responsible investment?

1. Are you familiar with the United Nation's Sustainable Development Goals?

(a) Yes

(b) No

[Answer if yes or no:] The United Nation's Sustainable Development Goals focus on seventeen goals relating to the environment, the climate, poverty, and other themes. The next page explains how Pensioenfonds Detailhandel uses these Sustainable Development Goals. 


\section{[Randomly assign one of the following parts]}

- Real \& 3 SDG default -

- Real \& 4 SDG default -

- Hypothetical \& 3 SDG default -

- Hypothetical \& 4 SDG default -

\section{[For all treatments]}

6. When do you think that the investment return is the highest?

[Info button: Investment return is the degree to which an investment earns money when taking the level of risk into account. In other words, more money results in a greater return. However, an investment that takes a greater risk to earn a certain amount results in a lower risk-adjusted return.]

(a) The investment return is highest for three sustainable development goals.

(b) The investment return is highest for four sustainable development goals.

(c) The investment return remains the same for three or four sustainable development goals.

(d) I don't know

7. Would you want Pensioenfonds Detailhandel to opt for four Sustainable Development Goals even if this decreased the risk-adjusted return?
(a) Yes
(b) No
(c) I don't know

8. Predict which percentage of Pensioenfonds Detailhandel's participants would also opt for four Sustainable Development Goals even if this decreased the risk-adjusted return.

(a) --- percent 


\section{[Part 2]}

The following questions aim to clarify your opinion of investing in a socially responsible way.

As opposed to previous questions, your answers in this part may not lead to Pensioenfonds Detailhandel taking direct action but can help us make decisions in the future.

How does Pensioenfonds Detailhandel currently make decisions regarding socially responsible investments? Pensioenfonds Detailhandel now implements our socially responsible investment policy in two ways:

i. by excluding companies

ii. by entering into discussions with companies.

The next question concerns excluding companies as a method of investing in a socially responsible way.

9. Pensioenfonds Detailhandel would like you to list which types of companies you think it should exclude from investments (several answers possible). Companies that...
(a) produce tobacco
(b) produce controversial weapons such as cluster bombs and landmines
(c) produce alcohol
(d) produce weapons (other than controversial weapons)
(e) infringe on human rights
(f) use forced labour
(g) have a negative impact on the environment
(h) are involved in corruption, extortion or bribery
(i) allow child labour 


\section{[Part 3]}

We would also like to ask you some background questions.

10. How willing are you to give to good causes without expecting anything in return? completely unwilling $1-10$ very willing

11. I am...
(a) Male
(b) Female
(c) Other

12. In what year were you born?
(a) Year of birth

13. What is the highest level of education you have completed?

(a) Preparatory secondary vocational education (VMBO) or lower general secondary education (MAVO or MULO)

(b) Higher general secondary education (HAVO)

(c) Pre-university education (HBS, HAVO, VWO) or pre-university education with Latin and/or Greek (Gymnasium)

(d) Intermediate vocational education level 1 (MBO)

(e) Intermediate vocational education level 2 (MBO)

(f) Intermediate vocational education level 3 (MBO)

(g) Intermediate vocational education level 4 (MBO)

(h) Higher professional education (HBO)

(i) University (WO)

(j) Other:

(k) I did not follow any of the above types of education

14. Did you vote in the last national parliamentary elections?
(a) Yes
(b) No
(c) I prefer not to answer 
15. If 'Yes' in previous question: Did you vote in the last national parliamentary elections?
(a) VVD
(b) CDA
(c) D66
(d) ChristenUnie
(e) PVV
(f) GroenLinks
(g) SP
(h) PvdA
(i) Partij voor de Dieren
(j) 50PLUS
(k) SGP
(1) DENK
(m) Forum voor Democratie
(n) Other, specifically:
(o) I prefer not to answer

We have a few questions regarding your financial situation. We understand that this information is sensitive and you can decide to skip these questions. However, as your answers to these questions are very valuable, we hope you will answer them. We will handle your data with due care. 
16. What is your household's net monthly income?

[Info button: net = your and your partner's income combined (if applicable) minus taxes and contributions.]

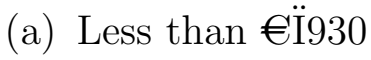
(b) Between $€ 930$ and $€ 1,500$
(c) Between $€ 1,500$ and $€ 2,000$
(d) Between $€ 2,000$ and $€ 2,500$
(e) Between $€ 2,500$ and $€ 3,000$
(f) Between $€ 3,000$ and $€ 4,000$
(g) Between $€ 4,000$ and $€ 7,000$
(h) Between $€ 7,000$ and $€ 10,000$
(i) Over $€ 10,000$
(j) I don’t know
(k) I prefer not to answer

17. How likely are you to discuss this survey with friends? completely unlikely $1-10$ very likely

18. We asked approximately 25,000 participants to complete this survey. How many people do you think will complete the survey?

19. If you win a VVV Gift Voucher, we will contact you by e-mail. If you want to win the prize, please tick the box.

$\square$ I want to win the prize.

20. If you would like to receive an e-mail with information about the results of this survey, please tick the box.

$\square$ I would like to receive information.

21. Please fill in your e-mail address below.

Thank you for participating.

Yours sincerely, Maastricht University and Pensioenfonds Detailhandel. 


\section{B Treatment 3 SDG Default (real and hypothetical)}

Pensioenfonds Detailhandel currently focuses on three of the United Nations' 17 Sustainable Development Goals. These three Sustainable Development Goals are:

1. Climate action:

e.g. taking urgent action to combat climate change such as by ensuring that businesses emit less CO2

2. Decent work and economic growth:

e.g. full employment for all women and men

3. Peace, justice, and strong institutions:

e.g. eradication of corruption and bribery

For more information on the Sustainable Development Goals, please click here: http://www. sdgnederland.nl/sdgs/

What does it mean to invest according to the United Nations' Sustainable Development Goals?

Pensioenfonds Detailhandel uses its influence in the companies in which it invests. In 2017, the pension fund spoke with a total of 246 company boards to promote sustainability.

\section{Royal Dutch Shell case:}

Working in collaboration with other parties, Pensioenfonds Detailhandel has contacted Shell on a number of occasions and made it clear that Shell has a lot of work ahead of it to achieve the objectives of the Paris Climate Agreement (to become CO2 neutral by 2015) and that it is urgent to do so.

The example of the diesel scandal in 2015:

Pensioenfonds Detailhandel contacted managers at Volkswagen (VW) in the aftermath of the diesel scandal. Pensioenfonds Detailhandel's involvement helped VW focus more on its long-term emissions strategy. 


\section{[Real treatment]}

\section{You have been selected!}

Pensioenfonds Detailhandel has decided to give you a say in how it determines its socially responsible investment policy.

\section{But how does this work?}

1. You can let Pensioenfonds Detailhandel know whether you agree with the current policy that focuses on three Sustainable Development Goals, or whether you would like to add a fourth one.

2. Your choice counts. If the majority of respondents chooses to add a fourth sustainable development goal, it will happen. The board of Pensioenfonds Detailhandel guarantees its implementation.

\section{[Hypothetical treatment]}

Pensioenfonds Detailhandel would like to know what your preferences are for socially responsible investment.

\section{But how does this work?}

1. You can let Pensioenfonds Detailhandel know whether you agree with the current policy that focuses on three Sustainable Development Goals, or whether you would like to add a fourth one.

2. Pensioenfonds Detailhandel is genuinely interested in your opinion and may take the results of the survey into account when making a decision.

Below, you find the fourth Sustainable Development Goal that you can add to the current policy.

Sustainable consumption and production: This Sustainable Development Goal ensures that parties, such as Pensioenfonds Detailhandel, are obliged to do the following: e.g. actively work against child labour, guarantee fair wages. 
Please note: implementing Sustainable Development Goals means that financial returns are not the only factor that is taken into consideration. Making investments with this in mind means that it is important to take the impact on the environment and wider society into account.

\section{The influence of your choice}

If Pensioenfonds Detailhandel focuses on four Sustainable Development Goals, this means that it will contact companies to discuss their sustainable business practices more often. The fund will also enter into discussions with companies about the fourth Sustainable Development Goal, in addition to the discussions it has about the other three Sustainable Development Goals.

As it is important that you understand this explanation, we will ask you a short question to test your understanding on the next page.

On the next page you will be asked the following:

3. Do you want Pensioenfonds Detailhandel to add the fourth sustainable development goal 'Responsible consumption and production'?
(a) Yes, add
(b) No, do not add
(c) I have no opinion regarding the matter

\section{Which of the following statements is correct?}

2. If a majority chooses 'Yes, add', Pensioenfonds Detailhandel

(a) guarantees to add 'Sustainable consumption and production' to its socially responsible investment policy as the fourth Sustainable Development Goal. The Board of Pensioenfonds Detailhandel has decided to implement the outcome of this vote.

(b) cannot guarantee that it will add 'Sustainable consumption and production' to its socially responsible investment policy as the fourth Sustainable Development Goal but may include the results of the survey in its choice. 


\section{[Real treatment]}

If a: That is correct. Pensioenfonds Detailhandel guarantees that it will add 'Sustainable consumption and production' to its socially responsible investment policy as the fourth Sustainable Development Goal if the majority of participants chooses 'Yes, add'. The Board of Pensioenfonds Detailhandel has decided to implement the outcome of this vote.

If $b$ : Your answer is incorrect. Pensioenfonds Detailhandel guarantees that it will add 'Sustainable consumption and production' to its socially responsible investment policy as the fourth Sustainable Development Goal if the majority of participants chooses 'Yes, add'. The Board of Pensioenfonds Detailhandel has decided to implement the outcome of this vote.

\section{[Hypothetical treatment]}

If a: Your answer is incorrect. Pensioenfonds Detailhandel cannot guarantee that your choice will lead to 'Sustainable consumption and production' being added as the fourth Sustainable Development Goal, but the fund is interested in your opinion.

If $b$ : This is correct. Pensioenfonds Detailhandel cannot guarantee that your choice will lead to 'Sustainable consumption and production' being added as the fourth Sustainable Development Goal, but the fund is interested in your opinion.

Please note that this is your choice. When considering your decision, please do so carefully.

3. Do you want Pensioenfonds Detailhandel to add the fourth sustainable development goal 'Responsible consumption and production'?
(a) Yes, add
(b) No, do not add
(c) I have no opinion regarding the matter

4. Would you have preferred receiving more information to make a decision regarding the development goals?
(a) Yes
(b) No

5. Please indicate below which percentage of participants of this survey will choose which answer regarding the question of adding the fourth Sustainable Development Goal.
(a) Yes, add:
-- percent
(b) No, do not add: --- percent
(c) I have no opinion regarding the matter: --- percent 


\section{Treatment 4 SDG Default (real and hypothetical)}

Pensioenfonds Detailhandel currently focuses on three of the United Nations' 17 Sustainable Development Goals. These three Sustainable Development Goals are:

1. Climate action:

e.g. taking urgent action to combat climate change such as by ensuring that businesses emit less CO2

2. Decent work and economic growth:

e.g. full employment for all women and men

3. Peace, justice, and strong institutions:

e.g. eradication of corruption and bribery

The future policy also includes this fourth goal

4. Sustainable consumption and production

For more information on the Sustainable Development Goals, please click here: http://www. sdgnederland.nl/sdgs/

What does it mean to invest according to the United Nations' Sustainable Development Goals?

Pensioenfonds Detailhandel uses its influence in the companies in which it invests. In 2017, the pension fund spoke with a total of 246 company boards to promote sustainability.

\section{Royal Dutch Shell case:}

Working in collaboration with other parties, Pensioenfonds Detailhandel has contacted Shell on a number of occasions and made it clear that Shell has a lot of work ahead of it to achieve the objectives of the Paris Climate Agreement (to become CO2 neutral by 2015) and that it is urgent to do so.

The example of the diesel scandal in 2015:

Pensioenfonds Detailhandel contacted managers at Volkswagen (VW) in the aftermath of the diesel scandal. Pensioenfonds Detailhandel's involvement helped VW focus more on its long-term emissions strategy. 


\section{[Real treatment]}

\section{You have been selected!}

Pensioenfonds Detailhandel has decided to give you a say in how it determines its socially responsible investment policy.

\section{But how does this work?}

1. You can let Pensioenfonds Detailhandel know whether you agree with the future policy that focuses on four Sustainable Development Goals, or whether you would like to leave out the fourth one.

2. Your choice counts. If the majority of respondents chooses that the fourth sustainable development goal must be left out, it will happen. The board of Pensioenfonds Detailhandel guarantees its implementation.

\section{[Hypothetical treatment]}

Pensioenfonds Detailhandel would like to know what your preferences are for socially responsible investment.

\section{But how does this work?}

1. You can let Pensioenfonds Detailhandel know whether you agree with the future policy that focuses on four Sustainable Development Goals, or whether you would like to leave out the fourth one.

2. Pensioenfonds Detailhandel is genuinely interested in your opinion and may take the results of the survey into account when making a decision.

Below, you find the fourth Sustainable Development Goal that you can leave out from the future policy.

Sustainable consumption and production: This Sustainable Development Goal ensures that parties, such as Pensioenfonds Detailhandel, are obliged to do the following: e.g. actively work against child labour, guarantee fair wages. 
Please note: implementing Sustainable Development Goals means that financial returns are not the only factor that is taken into consideration. Making investments with this in mind means that it is important to take the impact on the environment and wider society into account.

\section{The influence of your choice}

If Pensioenfonds Detailhandel focuses on four Sustainable Development Goals, this means that it will contact companies to discuss their sustainable business practices more often. The fund will also enter into discussions with companies about the fourth Sustainable Development Goal, in addition to the discussions it has about the other three Sustainable Development Goals.

As it is important that you understand this explanation, we will ask you a short question to test your understanding on the next page.

On the next page you will be asked the following:

3. Do you want Pensioenfonds Detailhandel to add the fourth sustainable development goal 'Responsible consumption and production'?

(a) Yes, leave it out

(b) No, do not leave it out

(c) I have no opinion regarding the matter

\section{Which of the following statements is correct?}

2. If a majority chooses 'Yes, leave it out', Pensioenfonds Detailhandel

(a) guarantees to leave out 'Sustainable consumption and production' of its socially responsible investment policy as the fourth Sustainable Development Goal. The Board of Pensioenfonds Detailhandel has decided to implement the outcome of this vote.

(b) cannot guarantee that it will leave out 'Sustainable consumption and production' of its socially responsible investment policy as the fourth Sustainable Development Goal but may include the results of the survey in its choice. 


\section{[Real treatment]}

If $a$ : That is correct. Pensioenfonds Detailhandel guarantees that it will leave out 'Sustainable consumption and production' of its socially responsible investment policy as the fourth Sustainable Development Goal if the majority of participants chooses 'Yes, leave it out'. The Board of Pensioenfonds Detailhandel has decided to implement the outcome of this vote.

If b: Your answer is incorrect. Pensioenfonds Detailhandel guarantees that it will leave out 'Sustainable consumption and production' of its socially responsible investment policy as the fourth Sustainable Development Goal if the majority of participants chooses 'Yes, leave it out'. The Board of Pensioenfonds Detailhandel has decided to implement the outcome of this vote.

\section{[Hypothetical treatment]}

If a: Your answer is incorrect. Pensioenfonds Detailhandel cannot guarantee that it will leave 'Sustainable consumption and production' out of its socially responsible investment policy as the fourth Sustainable Development Goal, but the fund is interested in your opinion.

If $b$ : This is correct. Pensioenfonds Detailhandel cannot guarantee that it will leave 'Sustainable consumption and production' out of its socially responsible investment policy as the fourth Sustainable Development Goal, but the fund is interested in your opinion.

Please note that this is your choice. When considering your decision, please do so carefully.

3. Do you want Pensioenfonds Detailhandel to leave out the fourth sustainable development goal 'Responsible consumption and production'?

(a) Yes, leave it out

(b) No, do not leave it out

(c) I have no opinion regarding the matter

4. Would you have preferred receiving more information to make a decision regarding the development goals?
(a) Yes
(b) No

5. Please indicate below which percentage of participants of this survey will choose which answer regarding the question of adding the fourth Sustainable Development Goal.

(a) Yes, leave it out: --- percent 
(b) No, do not leave it out: _--- percent

(c) I have no opinion regarding the matter: _-- percent 